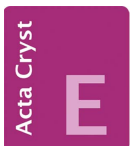

CRYSTALLOGRAPHIC COMMUNICATIONS

ISSN 2056-9890

Received 25 May 2020

Accepted 26 May 2020

Edited by W. T. A. Harrison, University of Aberdeen, Scotland

₹ Additional correspondence author, e-mail: kacrouse@gmail.com.

Keywords: crystal structure; Schiff base; hydrazine carbodithioate; hydrogen bonding; Hirshfeld surface analysis; DFT.

CCDC reference: 2005815

Supporting information: this article has supporting information at journals.iucr.org/e
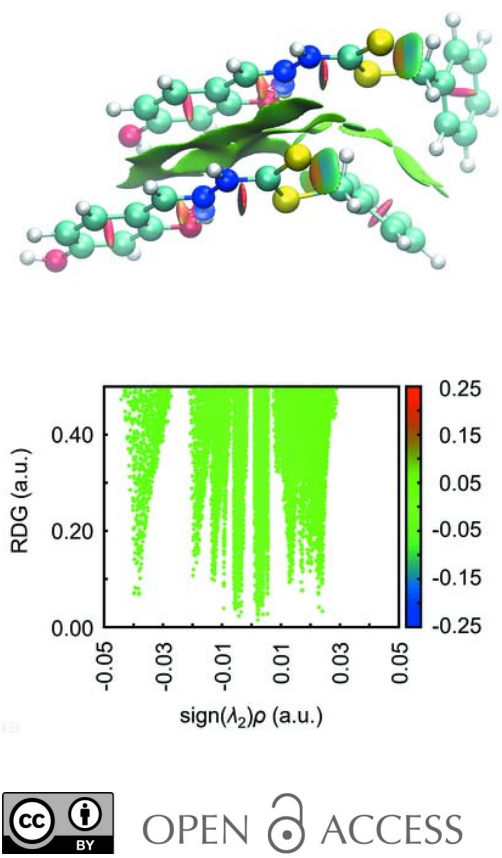

\section{4-[(1E)-(\{[(Benzylsulfanyl)methanethioyl]amino $\}-$ imino)methyl]benzene-1,3-diol chloroform hemisolvate: crystal structure, Hirshfeld surface analysis and computational study}

\author{
Nadia Liyana Khairuanuar, ${ }^{\mathrm{a}}$ Karen A. Crouse, ${ }^{\mathrm{a}} \ddagger$ Huey Chong Kwong, ${ }^{\mathrm{a}}$ Sang Loon \\ Tan $^{\mathrm{b}}$ and Edward R. T. Tiekink ${ }^{\mathrm{b}_{*}}$
}

a'Department of Chemistry, Faculty of Science, Universiti Putra Malaysia, UPM, Serdang 43400, Malaysia, and ${ }^{\mathbf{b}}$ Research
Centre for Crystalline Materials, School of Science and Technology, Sunway University, 47500 Bandar Sunway, Selangor
Darul Ehsan, Malaysia. *Correspondence e-mail: edwardt@sunway.edu.my

The title hydrazine carbodithioate chloroform hemisolvate, $2 \mathrm{C}_{15} \mathrm{H}_{14} \mathrm{~N}_{2} \mathrm{O}_{2} \mathrm{~S}_{2} \cdot-$ $\mathrm{CHCl}_{3}$, comprises two independent hydrazine carbodithioate molecules, $A$ and $B$, and a chloroform molecule; the latter is statistically disordered about its molecular threefold axis. The common features of the organic molecules include an almost planar, central $\mathrm{CN}_{2} \mathrm{~S}_{2}$ chromophore [r.m.s. deviation $=0.0203 \AA(A)$ and $0.0080 \AA(B)]$, an $E$ configuration about the imine bond and an intramolecular hydroxyl-O $-\mathrm{H} \cdots \mathrm{N}$ (imine) hydrogen bond. The major conformational difference between the molecules is seen in the relative dispositions of the phenyl rings as indicated by the values of the dihedral angles between the central plane and phenyl ring of $71.21(6)^{\circ}(A)$ and $54.73(7)^{\circ}(B)$. Finally, a difference is seen in the disposition of the outer hydroxyl-H atoms, having opposite relative orientations. In the calculated gas-phase structure, the entire molecule is planar with the exception of the perpendicular phenyl ring. In the molecular packing, the $A$ and $B$ molecules assemble into a two-molecule aggregate via $\mathrm{N}-\mathrm{H} \cdots \mathrm{S}$ hydrogen bonds and eight-membered $\{\cdots \mathrm{HNCS}\}_{2}$ synthons. The dimeric assemblies are connected into supramolecular chains via hydroxyl-O $-\mathrm{H}$... O(hydroxyl) hydrogen bonds and these are linked into a double-chain through hydroxy-O $-\mathrm{H} \cdots \pi$ (phenyl) interactions. The doublechains are connected into a three-dimensional architecture through phenyl-C$\mathrm{H} \cdots \mathrm{O}$ (hydroxyl) and phenyl- $\mathrm{C}-\mathrm{H} \cdots \pi$ (phenyl) interactions. The overall assembly defines columns along the $a$-axis direction in which reside the chloroform molecules, which are stabilized by chloroform-methine-C$\mathrm{H}$. S S (thione) and phenyl-C $-\mathrm{H} \cdots \mathrm{Cl}$ contacts. The analysis of the calculated Hirshfeld surfaces, non-covalent interaction plots and interaction energies confirm the importance of the above-mentioned interactions, but also of cooperative, non-standard interactions such as $\pi$ (benzene) $\cdots \pi$ (hydrogen-bondmediated-ring) contacts.

\section{Chemical context}

Schiff bases are ketone or aldehyde analogues in which the carbonyl group $(\mathrm{C}=\mathrm{O})$ is replaced by an azomethine group $(\mathrm{C}=\mathrm{N})$. Dithiocarbazato Schiff bases have received considerable attention because of the presence of both soft sulfur and hard nitrogen atoms (Mohamed et al., 2009), which enables them to readily form complexes with transition metals in different oxidation states (Centore et al., 2013). Dithiocarbazato Schiff bases and their metal complexes show a wide range of anti-bacterial (da Silva et al., 2011), anti-fungal (Nazimuddin et al., 1992), anti-viral (Pandeya et al., 1999) and 
anti-malarial (Dutta et al., 2006) activities. In addition, some dithiocarbazate derivatives display cytotoxicity towards a variety of cancer cell lines (Yusof et al., 2020) and some exhibit varying degrees of analgesic and anti-inflammatory activities (Zangrando et al., 2015).

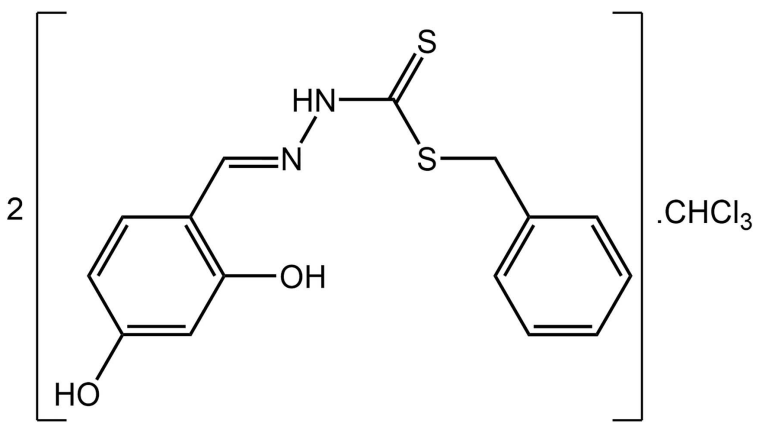

As part of on-going studies in this area (Rusli et al., 2020), herein the synthesis and $\mathrm{X}$-ray crystal structure determination of the title compound, $\mathrm{C}_{15} \mathrm{H}_{14} \mathrm{~N}_{2} \mathrm{O}_{2} \mathrm{~S}_{2} \cdot 0.5 \mathrm{CHCl}_{3}$, (I), is described. The experimental study is complemented by an analysis of the calculated Hirshfeld surfaces along with some computational chemistry.

\section{Structural commentary}

The crystallographic asymmetric unit of (I) comprises two independent hydrazine carbodithioate molecules and a chloroform solvent molecule of crystallization, with the latter disordered statistically about its molecular threefold axis. The molecular structures of the organic molecules are shown in Fig. 1 and selected geometric parameters are collected in Table 1. The central $\mathrm{CN}_{2} \mathrm{~S}_{2}$ atoms define an almost planar residue, exhibiting an r.m.s. deviation of $0.0203 \AA$ with maximum deviations to either side of the plane of 0.0264 (12) $\AA$, for the N2 atom, and 0.0319 (16) $\AA$ for N1; the C2 and C9 atoms lie, respectively, 0.161 (3) and 0.096 (4) $\AA$ out of the plane, in the direction of the $\mathrm{N} 2$ atom. The comparable plane for the S3-molecule is significantly more planar with an r.m.s. deviation $=0.0080 \AA$ with maximum deviations of 0.0131 (16) $\AA$ for the N3 atom and 0.0104 (12) $\AA$ for atom N4; the $\mathrm{C} 17$ atom lies 0.018 (3) $\AA$ out of the central plane in the direction of the $\mathrm{N} 3$ atom, and the $\mathrm{C} 24$ lies 0.123 (3) $\AA$ out of the plane in the direction of the N4 atom. The small difference in planarity is reflected in the $\mathrm{C} 1-\mathrm{N} 1-$ $\mathrm{N} 2-\mathrm{C} 2$ and $\mathrm{C} 16-\mathrm{N} 3-\mathrm{N} 4-\mathrm{C} 17$ torsion angles of 171.8 (2) and $179.3(2)^{\circ}$, respectively. More significant conformational differences are apparent in rest of the molecules: for the S1molecule, the dihedral angles between the central residue and terminal hydroxybenzene and phenyl rings are 6.18 (13) and $77.21(6)^{\circ}$, respectively, indicating close to co-planar and perpendicular relationships; the dihedral angle between the terminal rings is $71.22(8)^{\circ}$. The equivalent dihedral angles for the S3-molecule are $6.07(13), 54.53(6)$ and $54.73(7)^{\circ}$, respectively. The other notable difference between the molecules relates to the relative orientation of the hydroxy- $\mathrm{H}$ atoms in the 4-position, no doubt arising owing to the dictates of the molecular packing.
Table 1

Selected geometric parameters $\left(\AA,{ }^{\circ}\right)$ in $(\mathrm{I})$.

\begin{tabular}{lrrr}
\hline Parameter & S1-molecule & S3-molecule & $\begin{array}{r}\text { Geometry- } \\
\text { optimized }\end{array}$ \\
\hline C1-S1 & $1.680(3)$ & $1.675(2)$ & 1.650 \\
C1-S2 & $1.755(3)$ & $1.749(3)$ & 1.749 \\
C9-S2 & $1.816(3)$ & $1.823(3)$ & 1.815 \\
C1-N1 & $1.327(3)$ & $1.340(3)$ & 1.351 \\
N1-N2 & $1.377(3)$ & $1.376(3)$ & 1.355 \\
C2-N2 & $1.289(3)$ & $1.291(3)$ & 1.279 \\
& & & \\
S1-C1-S2 & $124.88(16)$ & $124.25(16)$ & 126.6 \\
S1-C1-N1 & $120.7(2)$ & $121.44(19)$ & 120.2 \\
S2-C1-N12 & $114.43(19)$ & $114.31(18)$ & 113.2 \\
C1-S2-C9 & $102.06(13)$ & $101.78(12)$ & 101.9 \\
C1-N1-N2 & $120.7(2)$ & $119.5(2)$ & 123.0 \\
N1-N2-C2 & $116.2(2)$ & $116.9(2)$ & 117.9 \\
N2-C2-C3 & $121.5(2)$ & $121.1(2)$ & 122.7 \\
& & & \\
S2-C9-C10-C11 & $97.7(3)$ & $-123.6(2)$ & 90.0 \\
S2-C9-C10-C15 & $-81.2(3)$ & $57.9(3)$ & -89.3 \\
S1-C1-S2-C9 & $2.2(2)$ & $-3.8(2)$ & 0.0 \\
S1-C1-N1-N2 & $-176.2(2)$ & $178.6(2)$ & -179.9 \\
S2-C1-N1-N2 & $3.9(3)$ & $-1.7(3)$ & 0.2 \\
C1-N1-N2-C2 & $171.8(2)$ & $179.3(2)$ & 179.9 \\
N1-N2-C2-C3 & $-178.8(2)$ & $179.2(2)$ & -180.0 \\
N2-C2-C3-C4 & $0.9(4)$ & $-3.4(4)$ & 0.0 \\
N2-C2-C3-C8 & $-179.3(2)$ & $177.0(2)$ & 180.0 \\
\hline
\end{tabular}

The relatively co-planar relationship between the central residue and the appended hydroxybenzene ring allows for the formation of an intramolecular hydroxy-O $-\mathrm{H} \cdots \mathrm{N}$ (imine) hydrogen bond in each molecule, Table 2 . The configuration about the imine bond is $E$ in each case. The comparison of geometric parameters in Table 1 shows a high degree of concordance. The $\mathrm{C}=\mathrm{S}$ bonds are significantly shorter than
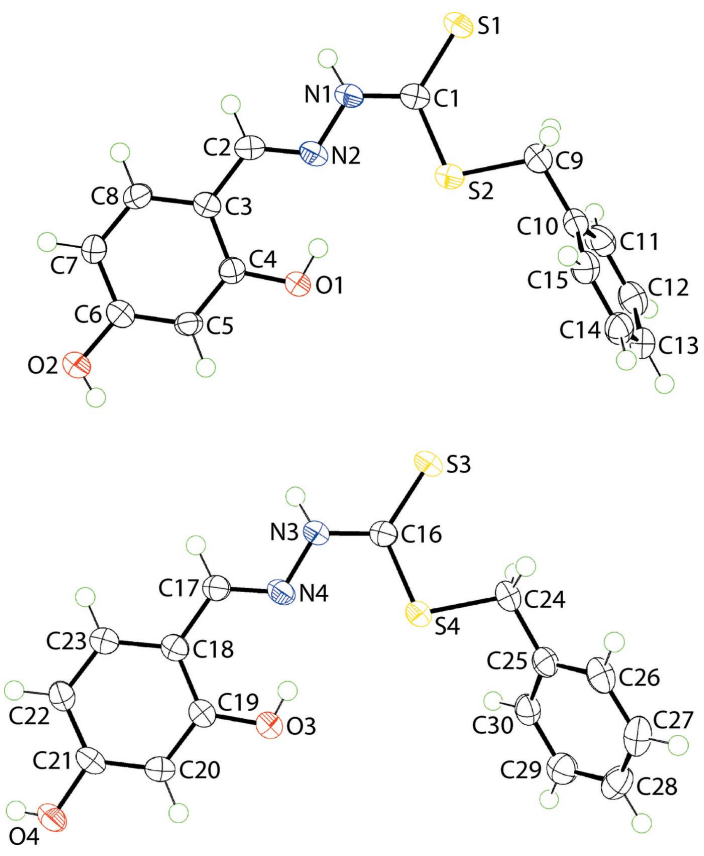

Figure 1

The molecular structures of the two independent hydrazine carbodithioate molecules in (I) showing the atom-labelling scheme and displacement ellipsoids at the $70 \%$ probability level. 
Table 2

Hydrogen-bond geometry $\left(\AA,^{\circ}\right)$.

$C g 1$ and $C g 2$ are the centroids of the $(\mathrm{C} 10-\mathrm{C} 15)$ and $(\mathrm{C} 25-\mathrm{C} 30)$ rings, respectively.

\begin{tabular}{lllll}
\hline$D-\mathrm{H} \cdots A$ & $D-\mathrm{H}$ & $\mathrm{H} \cdots A$ & $D \cdots A$ & $D-\mathrm{H} \cdots A$ \\
\hline $\mathrm{O} 1-\mathrm{H} 1 O \cdots \mathrm{N} 2$ & $0.83(3)$ & $1.91(3)$ & $2.653(3)$ & $148(3)$ \\
$\mathrm{O} 3-\mathrm{H} 3 O \cdots \mathrm{N} 4$ & $0.78(4)$ & $1.97(4)$ & $2.663(3)$ & $148(4)$ \\
$\mathrm{N} 1-\mathrm{H} 1 N \cdots \mathrm{S} 3^{\mathrm{i}}$ & $0.88(2)$ & $2.46(2)$ & $3.323(2)$ & $168(2)$ \\
$\mathrm{N} 3-\mathrm{H} 3 N \cdots \mathrm{S} 1^{\mathrm{i}}$ & $0.88(2)$ & $2.53(2)$ & $3.394(2)$ & $171(2)$ \\
$\mathrm{O} 2-\mathrm{H} 2 O \cdots \mathrm{O} 4^{\mathrm{ii}}$ & $0.76(4)$ & $2.09(4)$ & $2.841(3)$ & $170(4)$ \\
$\mathrm{O} 4-\mathrm{H} 4 O \cdots C g 1^{\mathrm{iii}}$ & $0.75(4)$ & $3.00(4)$ & $3.735(3)$ & $170(4)$ \\
$\mathrm{C} 27-\mathrm{H} 27 \cdots \mathrm{O} 2^{\text {iv }}$ & 0.95 & 2.59 & $3.206(4)$ & 122 \\
$\mathrm{C} 11-\mathrm{H} 11 \cdots C g 2^{\mathrm{v}}$ & 0.95 & 2.91 & $3.541(3)$ & 125 \\
$\mathrm{C} 29-\mathrm{H} 29 \cdots C g 1^{\text {vi }}$ & 0.95 & 2.87 & $3.506(3)$ & 125 \\
$\mathrm{C} 26-\mathrm{H} 26 \cdots \mathrm{C} 11^{\text {vii }}$ & 0.95 & 2.75 & $3.488(4)$ & 135 \\
$\mathrm{C} 31-\mathrm{H} 31 \cdots \mathrm{Cl} 2^{\text {vii }}$ & 1.00 & 2.66 & $3.512(4)$ & 143 \\
$\mathrm{C} 31^{\prime}-\mathrm{H} 31^{\prime} \cdots 1^{\mathrm{i}}$ & 1.00 & 2.77 & $3.579(4)$ & 139 \\
\hline
\end{tabular}

Symmetry codes: (i) $\quad-x+1,-y+1,-z$; (ii) $\quad-x+2,-y+1,-z+1$; (iii) $x+1, y+1, z ; \quad$ (iv) $x, y-1, z$; (v) $x-1, y, z$; (vi) $-x+1,-y,-z+1$; (vii) $-x+2,-y+1,-z ;$ (viii) $-x+1,-y+2,-z$.

the other $\mathrm{C}-\mathrm{S}$ bonds and this impacts upon the angles subtended at the $\mathrm{C} 1$ atom, being wider for those involving the thione-S atoms, and with the widest angle involving the two sulfur atoms.

\section{Theoretical molecular structure}

The two independent molecules of the hydrazine carbodithioate ester in (I) were subjected to gas-phase geometry optimization calculations using the density functional wB97XD level of theory (Chai \& Head-Gordon, 2008) and the Def2TZVP basis set (Weigend \& Ahlrichs, 2005) as available in Gaussian16 (Frisch et al., 2016). Selected geometric data for the optimized structure are included in Table 1 for comparison with the experimental molecular structures.

An overlay diagram for the experimental and theoretical, gas-phase structures is shown in Fig. 2. From here, the conformational differences between the two experimental structures are highlighted, especially the relative disposition of the terminal hydroxybenzene and phenyl rings. The geometric parameters extracted from the gas-phase structure reflect expectation but there are considerable conformational differences. Free from the restrictions of the crystalline manifold, the optimized structure is planar with the exception

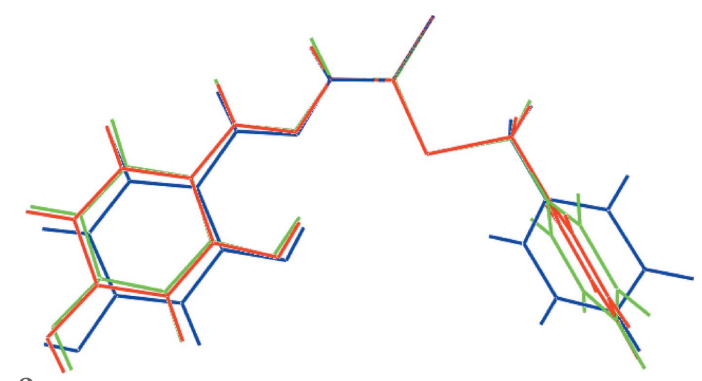

Figure 2

An overlay diagram of the two independent hydrazine carbodithioate molecules in (I): S1-molecule (red image) and S3-molecule (blue), and geometry optimized structure (green). The molecules have been overlapped so the $\mathrm{CS}_{2}$ residues are coincident. of the phenyl ring, which lies in a position perpendicular to the rest of the molecule. It is interesting to note that, qualitatively, the overall conformation in the S1-molecule more closely matches the gas-phase structure compared to the S3-molecule. This is reflected in the relative adjustments in the torsion angles, such as in the $\mathrm{S} 2-\mathrm{C} 9-\mathrm{C} 10-\mathrm{C} 11, \mathrm{C} 15$ torsion angles, Table 1.

\section{Supramolecular features}

In the molecular packing, the independent hydrazine carbodithioate molecules are connected by thioamide- $\mathrm{N}-$ $\mathrm{H}$...S(thione) hydrogen bonds to form a two-molecule aggregate. The $\mathrm{O} 2$-hydroxyl $\mathrm{H}$ atom forms a hydrogen bond with the hydroxyl-O4 atom, connecting the dimeric aggregates into a supramolecular chain. Centrosymmetrically related chains are connected into a double-chain via O4-hydroxy-O$\mathrm{H} \cdots \pi$ (phenyl) interactions as illustrated in Fig. $3(a)$. The
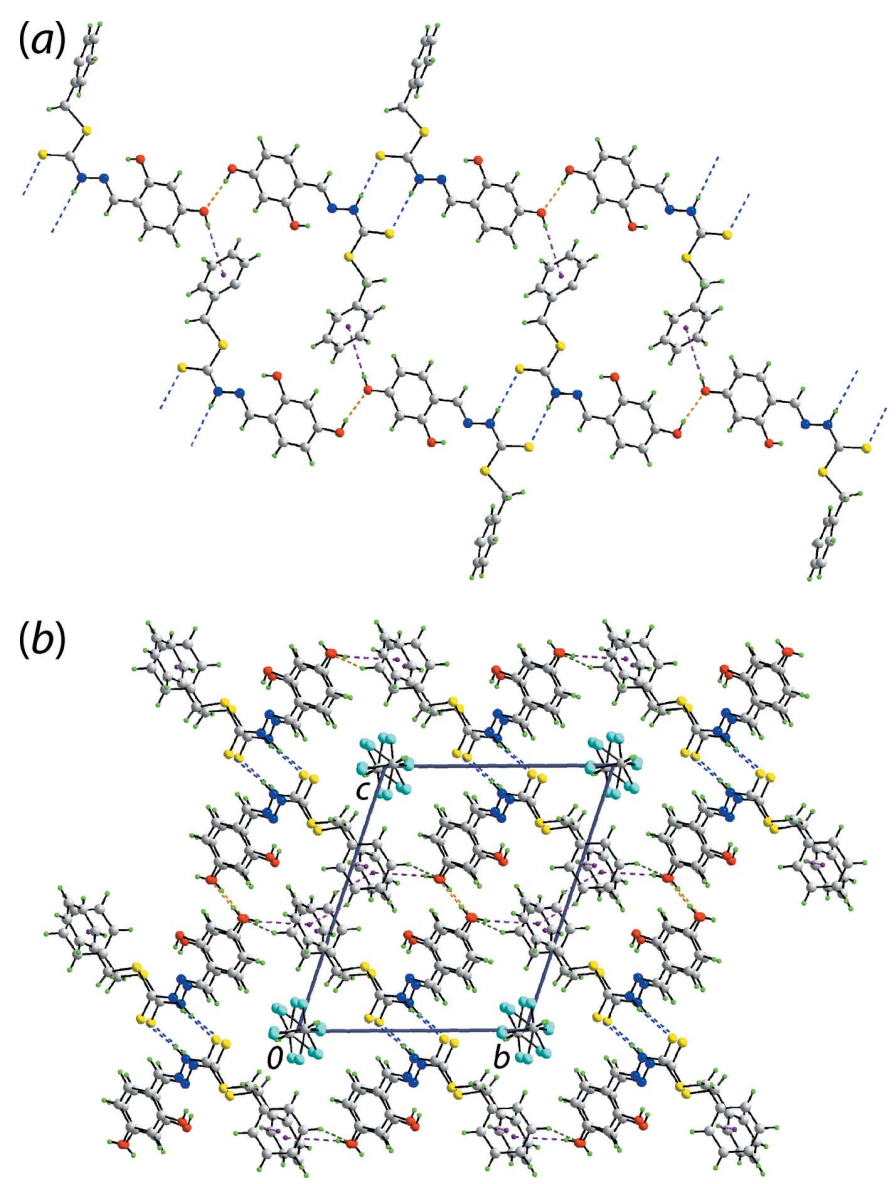

Figure 3

Molecular packing in (I): (a) the linear, supramolecular double-chain in which dimeric aggregates sustained by thioamide- $\mathrm{N}-\mathrm{H} \cdots \mathrm{S}$ (thioamide) hydrogen bonding, shown as blue dashed lines, are connected by hydroxyl-O $-\mathrm{H} \cdots \mathrm{O}$ (hydroxyl) (orange) and hydroxyl-O $-\mathrm{H} \cdots \pi$ (phen$\mathrm{yl}$ ) interactions (purple) and $(b)$ a view of the unit-cell contents shown in projection down the $a$ axis highlighting the three-dimensional framework and columns, parallel to the $a$-axis, in which reside the disordered $\mathrm{CHCl}_{3}$

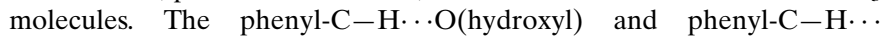
$\pi$ (phenyl) interactions are shown as green and pink dashed lines, respectively. 
(a)

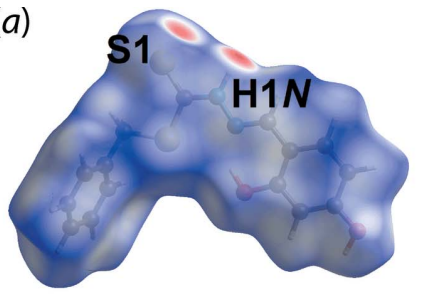

(b)

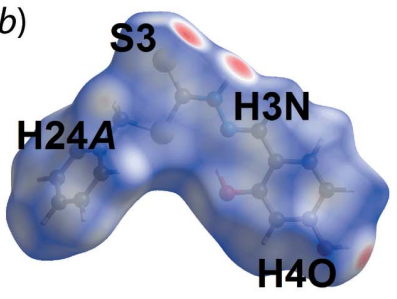

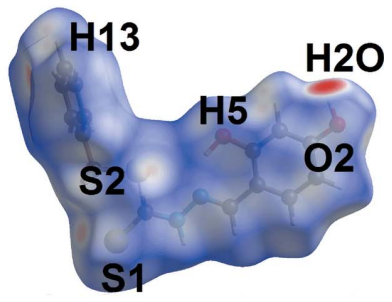

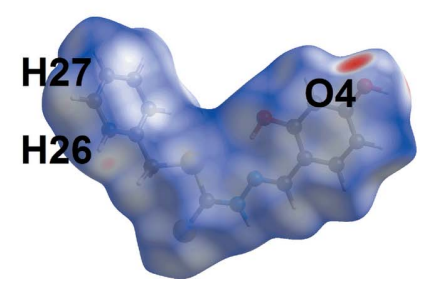

Figure 4

Views of the Hirshfeld surface for (I) mapped over $d_{\text {norm }}$ for the (a) S1containing molecule and (b) S3-molecule. The surfaces were mapped in the range -0.572 to +1.067 arbitrary units.

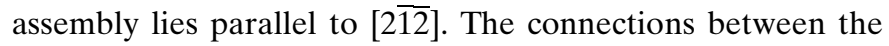
double-chains that form a three-dimensional architecture are of the type phenyl-C-H.OO(hydroxy) and phenyl-C$\mathrm{H} \cdots \pi$ (phenyl). This architecture defines columns, parallel to the $a$-axis direction, which accommodate the chloroform molecules, Fig. 3(b). The links between the host scaffold and the chloroform molecules are of the type methine-C$\mathrm{H} \cdots \mathrm{S}$ (thione) and phenyl-C- $\mathrm{H} \cdots \mathrm{Cl}$, as detailed in Table 2 .

\section{Analysis of the Hirshfeld surfaces}

The calculation of the Hirshfeld surfaces for (I) were conducted following literature procedures (Tan et al., 2019) employing CrystalExplorer17 (Turner et al., 2017) in order to reveal further details of the supramolecular association in the crystal. Calculations were performed on overall (I) and the individual S1- and S3-dithiocarbazate molecules. That the

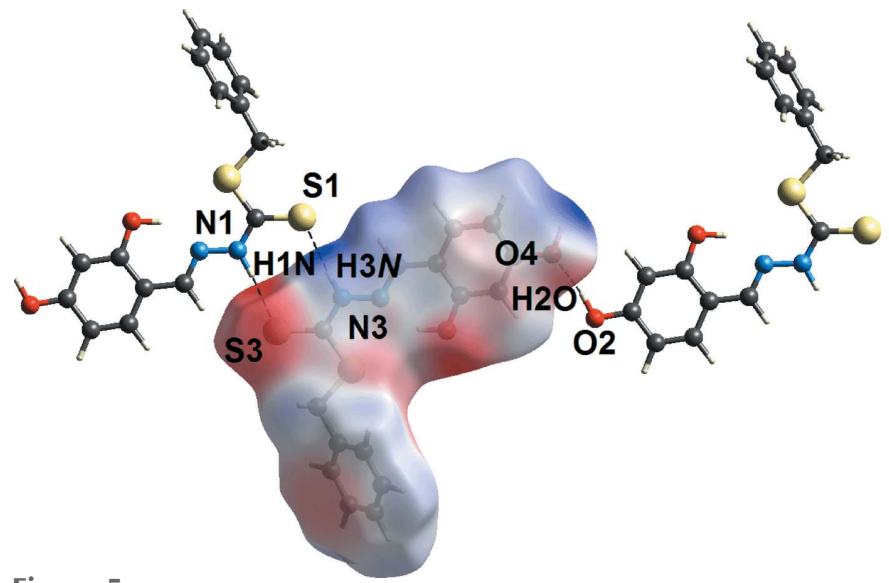

Figure 5

A view of the Hirshfeld surface mapped over the electrostatic potential for the S3-containing molecule in the range -0.055 to +0.134 a.u. The red and blue regions represent negative and positive electrostatic potentials, respectively.

Table 3

A summary of short interatomic contacts $(\AA)$ for $(\mathrm{I})^{a}$.

\begin{tabular}{lll}
\hline Contact & Distance & Symmetry operation \\
\hline $\mathrm{S} 1 \cdots \mathrm{H} 3 N^{b}$ & 2.40 & $1+x, 1-y,-z$ \\
$\mathrm{~S} 3 \cdots \mathrm{H} 1 N^{b}$ & 2.33 & $1+x, 1-y,-z$ \\
$\mathrm{O} 4 \cdots \mathrm{H} 2 O^{b}$ & 1.87 & $x, y, z$ \\
$\mathrm{~S} 1 \cdots \mathrm{H} 31$ & 2.87 & $1+x, 1-y,-z$ \\
$\mathrm{~S} 1 \cdots \mathrm{H} 31^{\prime}$ & 2.71 & $1+x, 1-y,-z$ \\
$\mathrm{~S} 2 \cdots \mathrm{H} 24 A$ & 2.82 & $x, y, z$ \\
$\mathrm{O} 2 \cdots \mathrm{H} 27$ & 2.53 & $x, 1+y, z$ \\
$\mathrm{C} 22 \cdots \mathrm{H} 27$ & 2.73 & $x, 1+y, z$ \\
$\mathrm{H} 5 \cdots \mathrm{H} 13$ & 2.17 & $1-x,-y, 1-z$ \\
$\mathrm{C} 11 \cdots \mathrm{H} 26$ & 2.66 & $2-x, 1-y,-z$ \\
\hline
\end{tabular}

Notes: (a) The interatomic distances are calculated in Crystal Explorer 17 (Turner et al., 2017) with the $X-\mathrm{H}$ bond lengths are adjusted to their neutron values; $(b)$ these interactions correspond to conventional hydrogen bonds.

thioamide and hydroxybenzene residues play a crucial role in the formation of directional interactions is indicated by the dark-red spots observed near the participating atoms on the Hirshfeld surfaces of the S1- and S3-containing molecules in Fig. 4. These observations are further confirmed by electrostatic potential mapping in which the $\mathrm{N}-\mathrm{H} \cdots \mathrm{S}$ and $\mathrm{O}-$ $\mathrm{H}$... O hydrogen bonds are shown as dark-blue (electropositive) and dark-red (electronegative) regions in Fig. 5. In the $d_{\text {norm }}$-surface mapping, some additional interactions corresponding to contacts listed in Table 3 are indicated by light-red spots around both dithiocarbazate molecules in Fig. 4. No significant contacts are indicated on the $d_{\text {norm }}$-mapped surfaces for the disorder components of the chloroform molecule (not shown). The $\mathrm{O} 4-\mathrm{H} 4 \mathrm{O} \cdots \pi(\mathrm{C} 10-\mathrm{C} 15)$ interaction is visible through $d_{\text {norm }}$ surface mapping in Fig. $6(a)$ and shapeindex surface mapping in Fig. 6(b).

As illustrated in Fig. 7(a), the overall two-dimensional fingerprint plot of (I) shows characteristic pseudo-symmetric wings along the $d_{\mathrm{e}}$ and $d_{\mathrm{i}}$ diagonal axes. This plot has also been
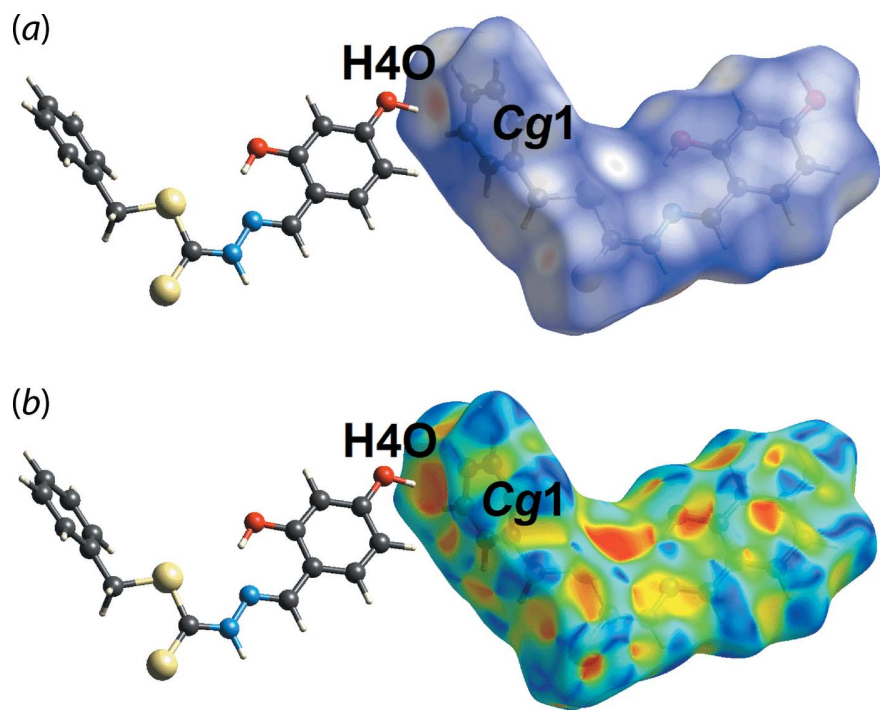

Figure 6

A view of the Hirshfeld surface mapped over $(a) d_{\text {norm }}$ and (b) the shapeindex property highlighting the intermolecular hydroxyl-O$\mathrm{H} \cdots \pi$ (phenyl) contacts as red and dark-orange regions, respectively. 
Table 4

The percentage contributions of interatomic contacts to the Hirshfeld surface for (I) and for the S1- and S3-molecules.

\begin{tabular}{llll}
\hline Contact & \multicolumn{2}{l}{ Percentage contribution } \\
\hline & $(\mathrm{I})$ & S1-molecule & S3-molecule \\
$\mathrm{H} \cdots \mathrm{H}$ & 26.7 & 29.7 & 27.6 \\
$\mathrm{H} \cdots \mathrm{Cl} / \mathrm{Cl} \cdot \mathrm{H}$ & 19.8 & 8.0 & 11.3 \\
$\mathrm{H} \cdots \mathrm{C} / \mathrm{C} \cdot \mathrm{H}$ & 17.6 & 21.8 & 23.0 \\
$\mathrm{H} \cdots \mathrm{S} / \mathrm{S} \cdots \mathrm{H}$ & 14.3 & 14.8 & 14.2 \\
$\mathrm{H} \cdots \mathrm{O} / \mathrm{O} \cdots \mathrm{H}$ & 10.3 & 12.1 & 10.0 \\
Others & 11.3 & 13.6 & 13.9 \\
\hline
\end{tabular}

delineated into $\mathrm{H} \cdots \mathrm{H}, \mathrm{H} \cdots \mathrm{Cl} / \mathrm{Cl} \cdots \mathrm{H}, \mathrm{H} \cdots \mathrm{C} / \mathrm{C} \cdots \mathrm{H}, \mathrm{H} \cdots \mathrm{S} /$ $\mathrm{S} \cdots \mathrm{H}$ and $\mathrm{H} \cdots \mathrm{O} / \mathrm{O} \cdots \mathrm{H}$ contacts as illustrated in Fig. 7(b)$(f)$; the percentage contributions to the Hirshfeld surface from different interatomic contacts are summarized in Table 4 for overall (I) and the individual S1- and S3-molecules.

The greatest contribution to the overall surface is from $\mathrm{H} \cdot \mathrm{H}$ contacts with the shortest contact, manifested in the peak tipped at $d_{\mathrm{e}}+d_{\mathrm{i}} \sim 2.2 \AA$ corresponding to the $\mathrm{H} 5 \cdots \mathrm{H} 13$ contact listed in Table 3 . The next most prominent contacts are due to $\mathrm{H} \cdots \mathrm{Cl} / \mathrm{Cl} \cdots \mathrm{H}$ surface contacts reflecting generally weak contacts involving the solvent chloroform molecule, Tables 2 and 3. The $\mathrm{H} \cdots \mathrm{C} / \mathrm{C} \cdots \mathrm{H}$ contacts on the Hirshfeld surface $(17.6 \%$ of the overall contribution) partly reflect the $\mathrm{O}-\mathrm{H} \cdots \pi$ contacts as discussed above. The significant contributions from $\mathrm{H} \cdots \mathrm{S} / \mathrm{S} \cdots \mathrm{H}(14.3 \%)$ and $\mathrm{H} \cdots \mathrm{O} / \mathrm{O} \cdots \mathrm{H}$ $(10.3 \%)$ contacts reflect the presence of the $\mathrm{N}-\mathrm{H} \cdots \mathrm{S}$ and $\mathrm{O}-\mathrm{H} \cdots \mathrm{O}$ hydrogen bonds. These appear as two sharp symmetric spikes in the fingerprint plots at $d_{\mathrm{e}}+d_{\mathrm{i}} \sim 2.3$ and $1.9 \AA$, respectively in Fig. 7(e) and (f). For overall (I), the sum of the percentage contributions from the other 16 different contacts, all of which occur at separations greater than the sum of the respective van der Waals radii, is less than $14 \%$.

Hirshfeld surface analysis can also be extremely useful for distinguishing between/confirming the presence of multiple molecules in the asymmetric unit (Jotani et al., 2019). The percentage contributions to the Hirshfeld surfaces for the S1and S3-molecules in (I) are included in Table 3. The major difference in the percentage contributions between overall (I) and the individual S1- and S3-molecules rests with the $\mathrm{H} \cdots \mathrm{Cl} /$ $\mathrm{Cl} \cdots \mathrm{H}$ interactions. These are approximately half for the latter, reflecting the fact that the chloroform molecule forms close to equal contributions to the surface contacts of the

(a)

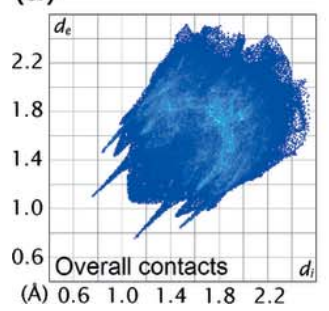

(b)

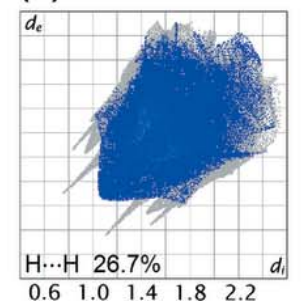

(c)

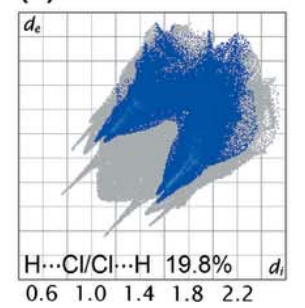

individual S1- and S3-molecules. The distinguishing features between the S1- and S3-molecules relate to the increased percentage contribution of $\mathrm{H} \cdots \mathrm{O} / \mathrm{O} \cdots \mathrm{H}$ contacts for the former, reflecting the $\mathrm{C} 27-\mathrm{H} 27 \cdots \mathrm{O} 2$ contact for which there is no equivalent for the $\mathrm{S} 3$-molecule, and also the increased $\mathrm{H} \cdots \mathrm{Cl} / \mathrm{Cl} \cdots \mathrm{H}$ contacts for the S3-molecule, reflecting the $\mathrm{H} \cdots \mathrm{Cl}$ contacts this molecule forms with the chloroform molecule.

\section{Computational chemistry}

Several of the non-covalent interactions present in (I) were qualitatively evaluated using NCIPLOT (Johnson et al., 2010) by verifying the strength of an interaction through visualization of the gradient isosurface based on the electron density derivatives obtained from wavefunction calculations (Contreras-García et al., 2011). Apart from the described contacts detected through Hirshfeld surface analyses, some additional non-covalent interactions were verified using NCI plots. These include the relatively large localized green domain observed between the hydroxybenzene fragment of the S1-molecule that extends towards the azomethine group of the S3-molecule, Fig. 8(a), indicating a weak interaction; overall $\operatorname{sign}\left(\lambda_{2}\right) \rho<-0.05$ a.u. This may arise from a $\pi-\pi$ interaction between the hydroxybenzene ring of the S1-molecule and the quasi-( $\mathrm{N} 4, \mathrm{C} 17-\mathrm{C} 19, \mathrm{O} 3, \mathrm{H} 3 \mathrm{O})$ aromatic ring of the S3-molecule. The ability of quasi- $\pi$-systems, where the ring is closed by a hydrogen bond, to engage in such interactions (Calvin \& Wilson, 1945; Karabiyık et al., 2014), including when one of the constituent atoms is a metal atom (Yeo et al., 2014), has been established in the literature. There is also evidence of weakly attractive regions correlating with interactions between the $\pi$-systems of the $(\mathrm{N} 2, \mathrm{C} 2-\mathrm{C} 4, \mathrm{O} 1, \mathrm{H} 1 O)$ and $(\mathrm{S} 4, \mathrm{C} 16, \mathrm{~N} 3, \mathrm{~N} 4)$ residues along with $\mathrm{C} 24-\mathrm{H} 24 A \cdots \mathrm{S} 2$ and $\mathrm{C} 14-\mathrm{H} 14, \mathrm{C} 15-\mathrm{H} 15 \cdots \pi(\mathrm{C} 25-\mathrm{C} 30)$ contacts.

Among all close contacts present in (I), the pairwise N1$\mathrm{H} 1 N \cdots \mathrm{S} 3 / \mathrm{N} 3-\mathrm{H} 3 N \cdots \mathrm{S} 1$ and $\mathrm{O} 2-\mathrm{H} 2 \mathrm{O} \cdots \mathrm{O} 4$ interactions exhibit a blue, i.e. strongly attractive, isosurface between the corresponding points of contact having a density values $\left[\operatorname{sign}\left(\lambda_{2}\right) \rho\right]$ more than -0.18 a.u., Fig. $6(b)$ and $(c)$. The intramolecular $\mathrm{O}-\mathrm{H} \cdots \mathrm{N}$ contacts reveal similar attractive interactions.

(d)

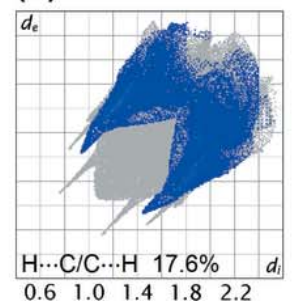

(e)

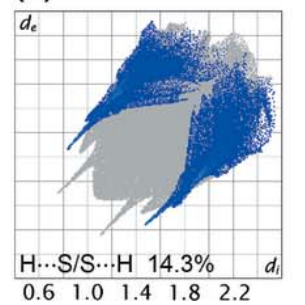

$(f)$

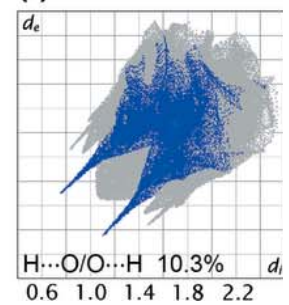

Figure 7

(a) The full two-dimensional fingerprint plot for (I) and fingerprint plots delineated into $(b) \mathrm{H} \cdots \mathrm{H},(c) \mathrm{H} \cdots \mathrm{Cl} / \mathrm{Cl} \cdots \mathrm{H},(d) \mathrm{H} \cdots \mathrm{C} / \mathrm{C} \cdots \mathrm{H},(e) \mathrm{H} \cdots \mathrm{S} /$ $\mathrm{S} \cdots \mathrm{H}$ and $(f) \mathrm{H} \cdots \mathrm{O} / \mathrm{O} \cdots \mathrm{H}$ contacts. 
Table 5

A summary of interaction energies $\left(\mathrm{kJ} \mathrm{mol}^{-1}\right)$ calculated for (I).

\begin{tabular}{|c|c|c|}
\hline Contact & Interaction Energy, $E_{\text {int }}^{\mathrm{BSSE}}$ & symmetry operation \\
\hline \multirow{2}{*}{\multicolumn{3}{|c|}{$\begin{array}{l}\pi(\mathrm{C} 3-\mathrm{C} 8) \cdots \text { quasi }-\pi(\mathrm{N} 4, \mathrm{C} 17-\mathrm{C} 19, \mathrm{O} 3, \mathrm{H} 3 O)+ \\
\text { quasi- } \pi(\mathrm{N} 2, \mathrm{C} 2-\mathrm{C} 4, \mathrm{O} 1, \mathrm{H} 1 O) \cdots \mathrm{quasi}-\pi(\mathrm{S} 4, \mathrm{C} 16, \mathrm{~N} 3, \mathrm{~N} 4)^{\prime}\end{array}$}} \\
\hline & & \\
\hline \multicolumn{3}{|c|}{$\begin{array}{l}\text { quas1- } \pi(\mathrm{N} 2, \mathrm{C} 2-\mathrm{C} 4, \mathrm{U} 1, \mathrm{H} 1 \mathrm{U}) \cdots \mathrm{quas} 1-\pi(\mathrm{S} 4, \mathrm{Cl}, \mathrm{N}, \mathrm{N} 3, \mathrm{~N} 4) \\
\mathrm{C} 24-\mathrm{H} 24 \mathrm{~A} \cdots \mathrm{S} 2+\end{array}$} \\
\hline $\mathrm{C} 15-\mathrm{H} 15 \cdots \pi(\mathrm{C} 25-\mathrm{C} 30)$ & -65.73 & $x, y, z$ \\
\hline \multicolumn{3}{|l|}{$\mathrm{N} 1-\mathrm{H} 1 N \cdots \mathrm{S} 3+$} \\
\hline $\mathrm{N} 3-\mathrm{H} 3 N \cdots \mathrm{S} 1$ & -59.79 & $1-x, 1-y,-z$ \\
\hline $\mathrm{C} 29-\mathrm{H} 29 \cdots \pi(\mathrm{C} 10-\mathrm{C} 15)$ & -26.28 & $1-x,-y, 1-z$ \\
\hline $\mathrm{C} 13-\mathrm{H} 13 \cdots \pi(\mathrm{C} 3-\mathrm{C} 8)$ & -20.08 & $1-x,-y, 1-z$ \\
\hline $\mathrm{O} 4-\mathrm{H} 4 O \cdots \pi(\mathrm{C} 10-\mathrm{C} 15)$ & -19.72 & $1+x, 1+y, z$ \\
\hline $\mathrm{C} 31^{\prime}-\mathrm{H} 31^{\prime} \ldots \mathrm{S} 1$ & -14.39 & $1-x, 1-y,-z$ \\
\hline $\mathrm{C} 31-\mathrm{H} 31 \cdots \mathrm{S} 1$ & -13.22 & $1-x, 1-y,-z$ \\
\hline $\mathrm{C} 31-\mathrm{H} 31 \cdots \mathrm{Cl} 2$ & -10.25 & $1-x, 2-y,-z$ \\
\hline $\mathrm{C} 27-\mathrm{H} 27 \cdots \pi(\mathrm{C} 18-\mathrm{C} 23)$ & -9.84 & $x,-1+y, z$ \\
\hline $\mathrm{C} 26-\mathrm{H} 26 \cdots \mathrm{Cl} 1$ & -5.27 & $2-x, 1-y,-z$ \\
\hline
\end{tabular}

To complement the NCIPLOT results, the strength of interaction for each close contact was quantified by calculation of the interaction energy in Gaussian16 (Frisch et al., 2016). All pairwise interactions were submitted for gas-phase energy calculation by the long-range corrected $\omega \mathrm{B} 97 \mathrm{XD}$ functional combining the D2 version of Grimme's dispersion model (Chai \& Head-Gordon, 2008) with Ahlrichs' valence triplezeta polarization basis sets $(\omega \mathrm{B} 97 \mathrm{XD} / \mathrm{def} 2-\mathrm{TZVP})$ (Weigend \& Ahlrichs, 2005), for which the dispersion model has been demonstrated to give better accuracy in interaction energy as compared to other computationally expensive models (Andersen et al., 2014). Counterpoise methods (Boys \& Bernardi, 1970; Simon et al., 1996) were applied to correct for basis set superposition error (BSSE) in all calculated energies.

Referring to Fig. 8(a), the combination of $\pi(\mathrm{C} 3-\mathrm{C} 8)-$ quasi$\pi(\mathrm{N} 4, \mathrm{C} 17-\mathrm{C} 19, \mathrm{O} 3, \mathrm{H} 3 O)$, quasi- $\pi(\mathrm{N} 2, \mathrm{C} 2-\mathrm{C} 4, \mathrm{O} 1, \mathrm{H} 1 O)$-quasi$\pi(\mathrm{S} 4, \mathrm{C} 16, \mathrm{~N} 3, \mathrm{~N} 4), \mathrm{C} 24-\mathrm{H} 24 A \cdots \mathrm{S} 2, \mathrm{C} 14-\mathrm{H} 14 \cdots \pi(\mathrm{C} 25-$ $\mathrm{C} 30)$ and $\mathrm{C} 15-\mathrm{H} 15 \cdots \pi(\mathrm{C} 25-\mathrm{C} 30)$ between S1- and S3-molecules exhibits the greatest interaction energy among all close contacts with an $E$ of $-65.73 \mathrm{~kJ} \mathrm{~mol}^{-1}$, Table 5 . This energy slightly exceeds that exhibited by the eight-membered $\{\cdots \mathrm{HNCS}\}_{2}$ synthon, being the second strongest interaction with $E=-59.79 \mathrm{~kJ} \mathrm{~mol}^{-1}$. The strength of the $\mathrm{N} 1-\mathrm{H} 1 N \cdots \mathrm{S} 3 /$ $\mathrm{N} 3-\mathrm{H} 3 N \cdots \mathrm{S} 1$ interaction is consistent with the energy range of -54.06 to $-57.99 \mathrm{~kJ} \mathrm{~mol}^{-1}$ displayed by the equiva-
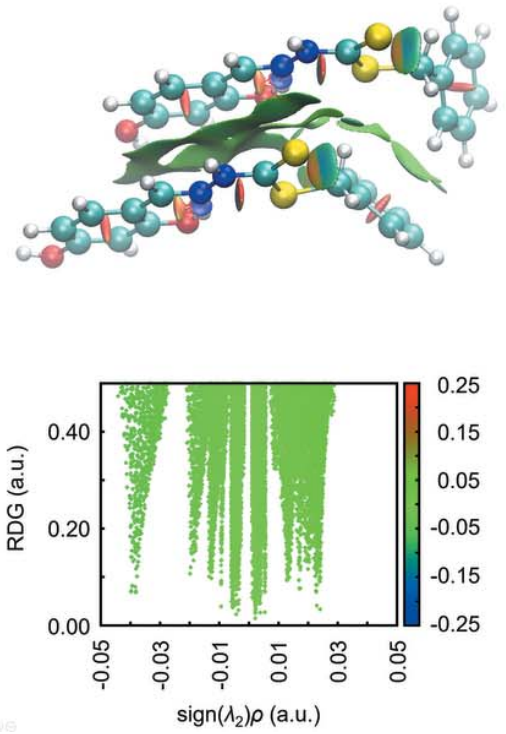
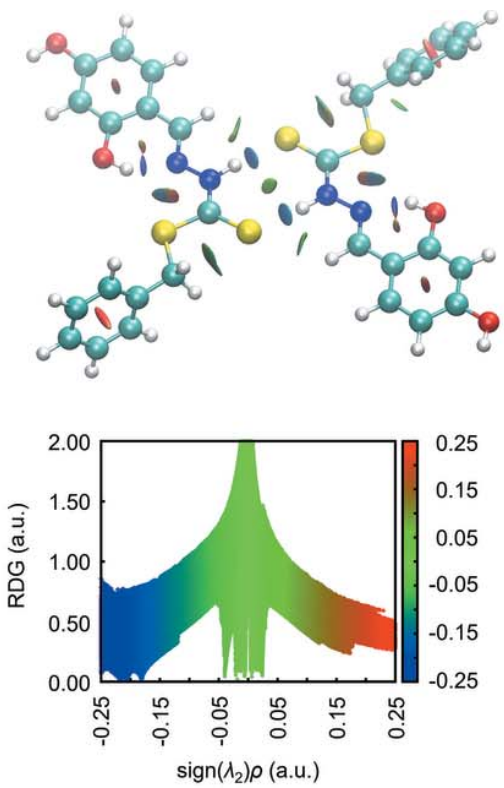
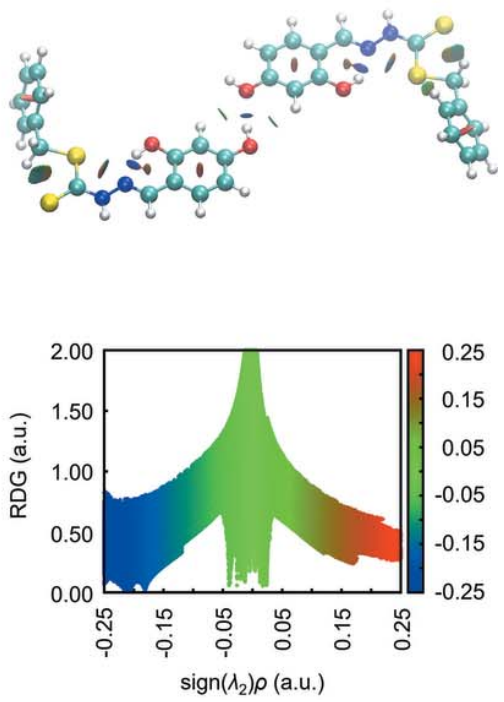

Figure 8

The non-covalent interaction plot and corresponding RDG versus $\operatorname{sign}\left(\lambda_{2}\right) \rho(r)$ plots for the dimeric aggregates sustained by $(a)$ a combination of $\pi(\mathrm{C} 3-$ $\mathrm{C} 8)-$ quasi- $\pi(\mathrm{N} 4, \mathrm{C} 17-\mathrm{C} 19, \mathrm{O} 3, \mathrm{H} 3 O)$, quasi- $\pi(\mathrm{N} 2, \mathrm{C} 2-\mathrm{C} 4, \mathrm{O} 1, \mathrm{H} 1 O)-$ quasi- $\pi(\mathrm{S} 4, \mathrm{C} 16, \mathrm{~N} 3, \mathrm{~N} 4), \mathrm{C} 24-\mathrm{H} 24 A \cdots \mathrm{S} 2, \mathrm{C} 14-\mathrm{H} 14 \cdots \pi(\mathrm{C} 25-\mathrm{C} 30)$ and $\mathrm{C} 15-$ $\mathrm{H} 15 \cdots \mathrm{p}(\mathrm{C} 25-\mathrm{C} 30)$ interactions between $\mathrm{S} 1-$ and S3-molecules, $(b) \mathrm{N} 1-\mathrm{H} 1 N \cdots \mathrm{S} 3$ and $\mathrm{N} 3-\mathrm{H} 3 N \cdots \mathrm{S} 1$ hydrogen bonds and $(c) \mathrm{O} 2-\mathrm{H} 2 \mathrm{O} \cdots \mathrm{O} 4$ interactions. 
Table 6

Experimental details.

\begin{tabular}{|c|c|}
\hline \multicolumn{2}{|l|}{ Crystal data } \\
\hline Chemical formula & $2 \mathrm{C}_{15} \mathrm{H}_{14} \mathrm{~N}_{2} \mathrm{O}_{2} \mathrm{~S}_{2} \cdot \mathrm{CHCl}_{3}$ \\
\hline$M_{\mathrm{r}}$ & 756.17 \\
\hline Crystal system, space group & Triclinic, $P \overline{1}$ \\
\hline Temperature (K) & 100 \\
\hline$a, b, c(\AA)$ & $9.3193(5), 12.7525(7), 15.7294(8)$ \\
\hline$\alpha, \beta, \gamma\left({ }^{\circ}\right)$ & $68.712(5), 74.217(5), 76.098(5)$ \\
\hline$V\left(\AA^{3}\right)$ & $1655.13(17)$ \\
\hline$Z$ & 2 \\
\hline Radiation type & $\mathrm{Cu} K \alpha$ \\
\hline$\mu\left(\mathrm{mm}^{-1}\right)$ & 5.23 \\
\hline Crystal size $(\mathrm{mm})$ & $0.11 \times 0.09 \times 0.03$ \\
\hline \multicolumn{2}{|l|}{ Data collection } \\
\hline Diffractometer & $\begin{array}{l}\text { Oxford Diffraction Xcalibur, Eos, } \\
\text { Gemini }\end{array}$ \\
\hline Absorption correction & $\begin{array}{l}\text { Multi-scan (CrysAlis RED; Oxford } \\
\text { Diffraction, 2006) }\end{array}$ \\
\hline$T_{\min }, T_{\max }$ & $0.766,1.000$ \\
\hline $\begin{array}{l}\text { No. of measured, independent and } \\
\text { observed }[I>2 \sigma(I)] \text { reflections }\end{array}$ & $24002,6572,5466$ \\
\hline$R_{\text {int }}$ & 0.034 \\
\hline$(\sin \theta / \lambda)_{\max }\left(\AA^{-1}\right)$ & 0.622 \\
\hline \multicolumn{2}{|l|}{ Refinement } \\
\hline$R\left[F^{2}>2 \sigma\left(F^{2}\right)\right], w R\left(F^{2}\right), S$ & $0.051,0.136,1.03$ \\
\hline No. of reflections & 6572 \\
\hline No. of parameters & 461 \\
\hline No. of restraints & 9 \\
\hline H-atom treatment & $\begin{array}{l}\mathrm{H} \text { atoms treated by a mixture of } \\
\text { independent and constrained } \\
\text { refinement }\end{array}$ \\
\hline$\Delta \rho_{\max }, \Delta \rho_{\min }\left(\mathrm{e} \AA^{-3}\right)$ & $1.04,-1.22$ \\
\hline
\end{tabular}

Computer programs: CrysAlis CCD and CrysAlis RED (Oxford Diffraction, 2006), SHELXT2014/4 (Sheldrick, 2015a), SHELXL2018/3 (Sheldrick, 2015b), ORTEP-3 for Windows (Farrugia, 2012), DIAMOND (Brandenburg, 2006) and publCIF (Westrip, 2010).

lent contacts in the cinnamaldehyde Schiff base of $S$-(4-methylbenzyl) dithiocarbazates calculated through wB97XD/6-31G $(d, p)$ (Yusof et al., 2017). Next, in terms of energy, is the $\mathrm{C} 29-\mathrm{H} 29 \cdots \pi(\mathrm{C} 10-\mathrm{C} 15)$ interaction with $E=-26.28 \mathrm{~kJ} \mathrm{~mol}^{-1}$, which is surprisingly higher than that of the more typical $\mathrm{O} 2-\mathrm{H} 2 \mathrm{O} \cdots \mathrm{O} 4$ interaction with an $E$ value of $-23.47 \mathrm{~kJ} \mathrm{~mol}^{-1}$. The energies of other interactions in the order of reducing strength are tabulated in Table 5.

\section{Database survey}

There are six literature precedents for X-ray crystal structure determinations of molecules of the general formula $(n-\mathrm{OH}-$ benzene $) \mathrm{C}=\mathrm{NN}(\mathrm{H}) \mathrm{C}(=\mathrm{S}) \mathrm{S} R$, five of which have the hydroxyl substituent in the 2-position enabling the formation of an intramolecular hydroxy-O $-\mathrm{H} \cdots \mathrm{N}$ (imine) hydrogen bond. In the most closely related compounds, i.e. with $2-\mathrm{OH}$ substituents, the $R$ group in the ester substituent is methyl (CSD refcode LUDGIC; Madanhire et al., 2015) and $n$-hexyl (TACYUU; Begum et al., 2016). An interesting feature of the latter structure is the presence of four independent molecules in the asymmetric unit. The other closely related structure has $R$ = benzyl and also a methoxy group in the 3-position of the hydroxybenzene ring (EHIXUQ; Yusof et al., 2016). Unlike the previous two molecules, which are very close to being planar, the benzyl group is perpendicular to the plane through the rest of the molecule. The three remaining structures have a methyl substituent at the imine-C atom. Two of these have 2-OH substituents in the benzene ring, one with $R=$ benzyl (QUCLIL; Biswal et al., 2015), with a twisted conformation, and the other with $R=\mathrm{CH}_{2}=\mathrm{CH}_{2}$ (NILRII; Lima et al., 2018), being a planar molecule. The sixth and final analogue is a 3-OH derivative with $R=$ benzyl (LUBNIH; Zangrando et al., 2015); this molecule exhibits a twisted conformation in its crystal.

\section{Synthesis and crystallization}

Two solutions, $S$-benzyldithiocarbazate $(5.0 \mathrm{~g}, 0.025 \mathrm{~mol}$ in $60 \mathrm{ml}$ of hot ethanol) and 2,4-dihydroxybenzaldehyde (3.45 g, $0.025 \mathrm{~mol}$ in $25 \mathrm{ml}$ ethanol) were mixed and heated until the initial volume was reduced by half. The yellow precipitate formed after cooling the mixture to room temperature was collected and washed with cold ethanol. It was recrystallized from ethanol solution and dried over silica gel for three days. Light-yellow prisms were obtained from its 1:1 diethyl ether/ chloroform solution by slow evaporation.

Yield: 4.98 g, 62\%; m.p. 463-465 K. FT-IR UATR (solid), $\lambda$ $\left(\mathrm{cm}^{-1}\right): 3310(\mathrm{O}-\mathrm{H}, v), 3094(\mathrm{~N}-\mathrm{H}, v), 1604(\mathrm{C}=\mathrm{N}, v), 1100$ $(\mathrm{N}-\mathrm{N}, v), 1024(\mathrm{C}=\mathrm{S}, v), 948(\mathrm{~S}=\mathrm{C}-\mathrm{S}, v) .{ }^{1} \mathrm{H}$ NMR $\left(400 \mathrm{MHz}, \mathrm{CDCl}_{3}\right): \delta 13.19(s, 1 \mathrm{H}, \mathrm{N}-\mathrm{H}), 10.21(s, 1 \mathrm{H}, \mathrm{O}-$ $\mathrm{H}), 10.07(s, 1 \mathrm{H}, \mathrm{O}-\mathrm{H}), 8.35(s, 1 \mathrm{H}, \mathrm{N}=\mathrm{CH}), 7.45(t, 2 \mathrm{H}, J=$ $7.5 \mathrm{~Hz}, \mathrm{Ph}), 7.36(t, 2 \mathrm{H}, J=7.5 \mathrm{~Hz}, \mathrm{Ph}), 7.21(t, 1 \mathrm{H}, J=7.5 \mathrm{~Hz}$, $\mathrm{Ph}), 6.29(s, 1 \mathrm{H}$, benzene $), 6.26(d, 2 \mathrm{H}, J=4.0 \mathrm{~Hz}$, benzene), $4.44\left(s, 2 \mathrm{H}, \mathrm{CH}_{2}\right) \cdot{ }^{13} \mathrm{C}\left\{{ }^{1} \mathrm{H}\right\}$-NMR $\left(100 \mathrm{MHz}, \mathrm{CDCl}_{3}\right): \delta \mathrm{ppm}$. $194.4(\mathrm{C}=\mathrm{S}), 162.1,159.6(\mathrm{C}-\mathrm{OH}), 146.5(\mathrm{~N}=\mathrm{C}), 129.7-$ 127.8 (Ph \& benzene), $38.0\left(\mathrm{CH}_{2}\right)$; GCMS (DI): $\mathrm{m} / z$ calculated for $\mathrm{C}_{15} \mathrm{H}_{14} \mathrm{~N}_{2} \mathrm{O}_{2} \mathrm{~S}_{2}^{+}\left[M^{+}\right]: 318$, found 318 .

\section{Refinement}

Crystal data, data collection and structure refinement details are summarized in Table 6 . The carbon-bound $\mathrm{H}$ atoms were placed in calculated positions $(\mathrm{C}-\mathrm{H}=0.95-1.00 \AA)$ and were included in the refinement in the riding-model approximation, with $U_{\text {iso }}(\mathrm{H})$ set to $1.2 U_{\text {eq }}(\mathrm{C})$. The $\mathrm{O}-$ and $\mathrm{N}$-bound $\mathrm{H}$ atoms were located in a difference-Fourier map but, were refined with $\mathrm{O}-\mathrm{H}(0.84 \pm 0.01 \AA)$ and $\mathrm{N}-\mathrm{H}(0.88 \pm 0.01 \AA)$ distance restraints, and with $U_{\text {iso }}(\mathrm{H})$ set to $1.5 U_{\text {eq }}(\mathrm{O})$ and to $1.2 U_{\text {eq }}(\mathrm{N})$, respectively. The $\mathrm{CHCl}_{3}$ solvent molecule is statistically disordered about the molecular threefold axis. The C31 atom is common to both conformations and the individual $\mathrm{Cl}$ atoms were refined anisotropically. A loose distance restraint for $\mathrm{C}-$ $\mathrm{Cl}$ was applied, i.e. $\mathrm{C}-\mathrm{Cl}=1.76 \pm 0.02 \AA$. The maximum and minimum residual electron density peaks of 1.04 and $1.22 \AA^{-3}$, respectively, are located 1.03 and $0.90 \AA$ from the $\mathrm{Cl}^{\prime}$ atom.

\section{Acknowledgements}

The intensity data were collected by Mohamed I. M. Tahir, Universiti Putra Malaysia. 


\section{Funding information}

Financial support from the Ministry of Science, Technology and Innovation Malaysia and the Universiti Putra Malaysia (RUGS 05-01-11-1243RU and FRGS 01-13-11-986FR) as well as scholarships (MyBrain15 and Graduate Research Fellowship) for NLK are gratefully acknowledged. Crystallographic research at Sunway University is supported by Sunway University Sdn Bhd (grant No. STR-RCTR-RCCM-0012019).

\section{References}

Andersen, C. L., Jensen, C. S., Mackeprang, K., Du, L., Jørgensen, S. \& Kjaergaard, H. G. (2014). J. Phys. Chem. A, 118, 11074-11082.

Begum, M. S., Howlader, M. B. H., Sheikh, M. C., Miyatake, R. \& Zangrando, E. (2016). Acta Cryst. E72, 290-292.

Biswal, D., Pramanik, N. R., Chakrabarti, S., Chakraborty, N., Acharya, K., Mandal, S. S., Ghosh, S., Drew, M. G. B., Mondal, T. K. \& Biswas, S. (2015). New J. Chem. 39, 2778-2794.

Boys, S. F. \& Bernardi, F. (1970). Mol. Phys. 19, 553-566.

Brandenburg, K. (2006). DIAMOND. Crystal Impact GbR, Bonn, Germany.

Calvin, M. \& Wilson, K. W. (1945). J. Am. Chem. Soc. 67, 2003-2007.

Centore, R., Takjoo, R., Capobianco, A. \& Peluso, A. (2013). Inorg. Chim. Acta, 404, 29-33.

Chai, J. D. \& Head-Gordon, M. (2008). Phys. Chem. Chem. Phys. 10, 6615-6620.

Contreras-García, J., Johnson, E. R., Keinan, S., Chaudret, R., Piquemal, J.-P., Beratan, D. N. \& Yang, W. (2011). J. Chem. Theory Comput. 7, 625-632.

Dutta, B., Some, S. \& Ray, J. K. (2006). Tetrahedron Lett. 47, 377-379.

Farrugia, L. J. (2012). J. Appl. Cryst. 45, 849-854.

Frisch, M. J., et al. (2016). Gaussian16, Revision A. 03. Gaussian, Inc., Wallingford, CT, USA.

Johnson, E. R., Keinan, S., Mori-Sánchez, P., Contreras-García, J., Cohen, A. J. \& Yang, W. (2010). J. Am. Chem. Soc. 132, 6498-6506.

Jotani, M. M., Wardell, J. L. \& Tiekink, E. R. T. (2019). Z. Kristallogr. Cryst. Mater. 234, 43-57.

Karabıyık, H., Sevinçek, R. \& Karabıyık, H. (2014). J. Mol. Struct. 1064, 135-149.
Lima, F. C., Silva, T. S., Martins, C. H. G. \& Gatto, C. C. (2018). Inorg. Chim. Acta, 483, 464-472.

Madanhire, T., Abrahams, A., Hosten, E. C. \& Betz, R. (2015). Z. Kristallogr. - New Cryst. Struct. 230, 13-14.

Mohamed, G. G., Omar, M. M. \& Ibrahim, A. A. (2009). Eur. J. Med. Chem. 44, 4801-4812.

Nazimuddin, M., Ali, M. A., Smith, F. E. \& Mridha, M. A. (1992). Transition Met. Chem. 17, 74-78.

Oxford Diffraction (2006). CrysAlis CCD and CrysAlis RED. Oxford Diffraction Ltd, Abingdon, England.

Pandeya, S. N., Sriram, D., Nath, G. \& DeClercq, E. (1999). Eur. J. Pharm. Sci. 9, 25-31.

Rusli, A. F., Kwong, H. C., Crouse, K. A., Jotani, M. M. \& Tiekink, E. R. T. (2020). Acta Cryst. E76, 208-213.

Sheldrick, G. M. (2015a). Acta Cryst. A71, 3-8.

Sheldrick, G. M. (2015b). Acta Cryst. C71, 3-8.

Silva, C. M. da, da Silva, D. L., Modolo, L. V., Alves, R. B., de Resende, M. A. \& Martins, C. V. B. de Fátima (2011). J. Adv. Res. 2 , 1-8.

Simon, S., Duran, M. \& Dannenberg, J. J. (1996). J. Chem. Phys. 105, 11024-11031.

Tan, S. L., Jotani, M. M. \& Tiekink, E. R. T. (2019). Acta Cryst. E75, 308-318.

Turner, M. J., Mckinnon, J. J., Wolff, S. K., Grimwood, D. J., Spackman, P. R., Jayatilaka, D. \& Spackman, M. A. (2017). Crystal Explorer 17. The University of Western Australia.

Weigend, F. \& Ahlrichs, R. (2005). Phys. Chem. Chem. Phys. 7, 32973305 .

Westrip, S. P. (2010). J. Appl. Cryst. 43, 920-925.

Yeo, C. I., Halim, S. N. A., Ng, S. W., Tan, S. L., Zukerman-Schpector, J., Ferreira, M. A. B. \& Tiekink, E. R. T. (2014). Chem. Commun. 50, 5984-5986.

Yusof, E. N. M., Ishak, N. N. M., Latif, M. A. M., Tahir, M. I. M., Sakoff, J. A., Page, A. J., Tiekink, E. R. T. \& Ravoof, T. B. S. A. (2020). Res. Chem. Intermed. 46, 2351-2379.

Yusof, E. N. M., Jotani, M. M., Tiekink, E. R. T. \& Ravoof, T. B. S. A. (2016). Acta Cryst. E72, 516-521.

Yusof, E. N. M., Tahir, M. I. M., Ravoof, T. B. S. A., Tan, S. L. \& Tiekink, E. R. T. (2017). Acta Cryst. E73, 543-549.

Zangrando, E., Islam, M. T., Islam, M. A.-A. A. A., Sheikh, M. C., Tarafder, M. T. H., Miyatake, R., Zahan, R. \& Hossain, M. A. (2015). Inorg. Chim. Acta, 427, 278-284. 


\section{supporting information}

Acta Cryst. (2020). E76, 990-997 [https://doi.org/10.1107/S2056989020007070]

4-[(1E)-(\{[(Benzylsulfanyl)methanethioyl]amino\}imino)methyl]benzene-1,3-diol chloroform hemisolvate: crystal structure, Hirshfeld surface analysis and computational study

Nadia Liyana Khairuanuar, Karen A. Crouse, Huey Chong Kwong, Sang Loon Tan and Edward R. T. Tiekink

Computing details

Data collection: CrysAlis CCD (Oxford Diffraction, 2006); cell refinement: CrysAlis RED (Oxford Diffraction, 2006); data reduction: CrysAlis RED (Oxford Diffraction, 2006); program(s) used to solve structure: SHELXT2014/4 (Sheldrick, 2015a); program(s) used to refine structure: SHELXL2018/3 (Sheldrick, 2015b); molecular graphics: ORTEP-3 for Windows (Farrugia, 2012), DIAMOND (Brandenburg, 2006); software used to prepare material for publication: publCIF (Westrip, 2010).

4-[(1E)-(\{[(Benzylsulfanyl)methanethioyl]amino\}imino)methyl]benzene-1,3-diol chloroform hemisolvate

Crystal data

$2 \mathrm{C}_{15} \mathrm{H}_{14} \mathrm{~N}_{2} \mathrm{O}_{2} \mathrm{~S}_{2} \cdot \mathrm{CHCl}_{3}$

$M_{r}=756.17$

Triclinic, $P \overline{1}$

$a=9.3193(5) \AA$

$b=12.7525(7) \AA$

$c=15.7294(8) \AA$

$\alpha=68.712(5)^{\circ}$

$\beta=74.217(5)^{\circ}$

$\gamma=76.098(5)^{\circ}$

$V=1655.13(17) \AA^{3}$

Data collection

Oxford Diffraction Xcalibur, Eos, Gemini diffractometer

Radiation source: Enhance $(\mathrm{Cu}) \mathrm{X}$-ray Source Graphite monochromator

Detector resolution: 16.1952 pixels $\mathrm{mm}^{-1}$

$\omega$ scans

Absorption correction: multi-scan (CrysAlis RED; Oxford Diffraction, 2006)

$T_{\min }=0.766, T_{\max }=1.000$
$Z=2$

$F(000)=780$

$D_{\mathrm{x}}=1.517 \mathrm{Mg} \mathrm{m}^{-3}$

$\mathrm{Cu} K \alpha$ radiation, $\lambda=1.54178 \AA$

Cell parameters from 9024 reflections

$\theta=3.1-73.3^{\circ}$

$\mu=5.23 \mathrm{~mm}^{-1}$

$T=100 \mathrm{~K}$

Prism, yellow

$0.11 \times 0.09 \times 0.03 \mathrm{~mm}$

24002 measured reflections 6572 independent reflections 5466 reflections with $I>2 \sigma(I)$

$R_{\text {int }}=0.034$

$\theta_{\max }=73.5^{\circ}, \theta_{\min }=3.1^{\circ}$

$h=-11 \rightarrow 11$

$k=-15 \rightarrow 15$

$l=-19 \rightarrow 19$ 


\section{Refinement}

Refinement on $F^{2}$

Least-squares matrix: full

$R\left[F^{2}>2 \sigma\left(F^{2}\right)\right]=0.051$

$w R\left(F^{2}\right)=0.136$

$S=1.03$

6572 reflections

461 parameters

9 restraints

Primary atom site location: structure-invariant direct methods
Secondary atom site location: difference Fourier map

Hydrogen site location: mixed

$\mathrm{H}$ atoms treated by a mixture of independent and constrained refinement

$w=1 /\left[\sigma^{2}\left(F_{\mathrm{o}}^{2}\right)+(0.0674 P)^{2}+2.3512 P\right]$ where $P=\left(F_{\mathrm{o}}{ }^{2}+2 F_{\mathrm{c}}{ }^{2}\right) / 3$

$(\Delta / \sigma)_{\max }<0.001$

$\Delta \rho_{\max }=1.04 \mathrm{e} \AA^{-3}$

$\Delta \rho_{\min }=-1.22$ e $\AA^{-3}$

Special details

Geometry. All esds (except the esd in the dihedral angle between two 1.s. planes) are estimated using the full covariance matrix. The cell esds are taken into account individually in the estimation of esds in distances, angles and torsion angles; correlations between esds in cell parameters are only used when they are defined by crystal symmetry. An approximate (isotropic) treatment of cell esds is used for estimating esds involving l.s. planes.

Fractional atomic coordinates and isotropic or equivalent isotropic displacement parameters $\left(\AA^{2}\right)$

\begin{tabular}{|c|c|c|c|c|c|}
\hline & $x$ & $y$ & $z$ & $U_{\text {iso }} * / U_{\text {eq }}$ & Occ. $(<1)$ \\
\hline S1 & $0.25089(8)$ & $0.29506(6)$ & $0.04795(4)$ & $0.02579(17)$ & \\
\hline $\mathrm{S} 2$ & $0.31964(8)$ & $0.20219(6)$ & $0.24284(4)$ & $0.02445(16)$ & \\
\hline $\mathrm{O} 1$ & $0.4742(2)$ & $0.34505(16)$ & $0.36255(13)$ & $0.0236(4)$ & \\
\hline $\mathrm{H} 1 \mathrm{O}$ & $0.441(4)$ & $0.342(3)$ & $0.3195(17)$ & $0.035 *$ & \\
\hline $\mathrm{O} 2$ & $0.7068(2)$ & $0.59223(17)$ & $0.42660(14)$ & $0.0248(4)$ & \\
\hline $\mathrm{H} 2 \mathrm{O}$ & $0.719(4)$ & $0.538(3)$ & $0.467(3)$ & $0.037^{*}$ & \\
\hline N1 & $0.3459(2)$ & 0.40638 (19) & $0.12744(15)$ & $0.0216(4)$ & \\
\hline $\mathrm{H} 1 \mathrm{~N}$ & $0.334(4)$ & $0.4674(17)$ & $0.0787(14)$ & $0.026^{*}$ & \\
\hline N2 & $0.4002(2)$ & 0.41587 (19) & $0.19707(15)$ & $0.0203(4)$ & \\
\hline $\mathrm{C} 1$ & $0.3070(3)$ & $0.3092(2)$ & $0.13557(18)$ & $0.0210(5)$ & \\
\hline $\mathrm{C} 2$ & $0.4523(3)$ & $0.5085(2)$ & $0.17831(17)$ & $0.0208(5)$ & \\
\hline $\mathrm{H} 2$ & 0.449270 & 0.565398 & 0.119382 & $0.025^{*}$ & \\
\hline $\mathrm{C} 3$ & $0.5149(3)$ & $0.5276(2)$ & $0.24467(17)$ & $0.0191(5)$ & \\
\hline $\mathrm{C} 4$ & $0.5250(3)$ & $0.4457(2)$ & $0.33341(17)$ & $0.0185(5)$ & \\
\hline $\mathrm{C} 5$ & $0.5878(3)$ & $0.4678(2)$ & $0.39452(17)$ & $0.0196(5)$ & \\
\hline H5 & 0.592987 & 0.413031 & 0.454159 & $0.024 *$ & \\
\hline C6 & $0.6428(3)$ & $0.5688(2)$ & $0.36936(18)$ & $0.0200(5)$ & \\
\hline C7 & $0.6322(3)$ & $0.6526(2)$ & $0.28227(18)$ & $0.0219(5)$ & \\
\hline H7 & 0.667601 & 0.722731 & 0.265441 & $0.026^{*}$ & \\
\hline $\mathrm{C} 8$ & $0.5691(3)$ & $0.6303(2)$ & $0.22206(18)$ & $0.0216(5)$ & \\
\hline H8 & 0.562034 & 0.686290 & 0.163188 & $0.026^{*}$ & \\
\hline C9 & $0.2662(3)$ & $0.0836(2)$ & $0.2270(2)$ & $0.0285(6)$ & \\
\hline H9A & 0.166479 & 0.106817 & 0.209163 & $0.034 *$ & \\
\hline H9B & 0.341362 & 0.059511 & 0.176822 & $0.034 *$ & \\
\hline $\mathrm{C} 10$ & $0.2594(3)$ & $-0.0138(2)$ & $0.31778(19)$ & $0.0241(5)$ & \\
\hline C11 & $0.1216(3)$ & $-0.0316(2)$ & $0.3794(2)$ & $0.0279(6)$ & \\
\hline H11 & 0.031362 & 0.016945 & 0.363684 & $0.034^{*}$ & \\
\hline C12 & $0.1153(3)$ & $-0.1195(3)$ & $0.4632(2)$ & $0.0283(6)$ & \\
\hline
\end{tabular}




\begin{tabular}{|c|c|c|c|c|c|}
\hline H12 & 0.020831 & -0.131504 & 0.504563 & $0.034^{*}$ & \\
\hline $\mathrm{C} 13$ & $0.2467(3)$ & $-0.1903(2)$ & $0.48719(19)$ & $0.0248(6)$ & \\
\hline H13 & 0.242045 & -0.249847 & 0.545235 & $0.030^{*}$ & \\
\hline $\mathrm{C} 14$ & $0.3851(3)$ & $-0.1742(2)$ & $0.4262(2)$ & $0.0251(6)$ & \\
\hline H14 & 0.474899 & -0.223164 & 0.442161 & $0.030^{*}$ & \\
\hline $\mathrm{C} 15$ & $0.3914(3)$ & $-0.0863(2)$ & $0.34213(19)$ & $0.0250(6)$ & \\
\hline H15 & 0.485897 & -0.075124 & 0.300618 & $0.030^{*}$ & \\
\hline S3 & $0.73253(7)$ & $0.34482(6)$ & $0.03293(4)$ & $0.02366(16)$ & \\
\hline S4 & $0.83946(7)$ & $0.24109(6)$ & $0.21556(4)$ & $0.02302(16)$ & \\
\hline $\mathrm{O} 3$ & $0.9879(2)$ & $0.37367(16)$ & $0.34167(13)$ & $0.0256(4)$ & \\
\hline $\mathrm{H} 3 \mathrm{O}$ & $0.960(4)$ & $0.372(3)$ & $0.300(3)$ & $0.038^{*}$ & \\
\hline $\mathrm{O} 4$ & $1.2098(2)$ & $0.60394(18)$ & $0.42605(14)$ & $0.0266(4)$ & \\
\hline $\mathrm{H} 4 \mathrm{O}$ & $1.225(4)$ & $0.663(3)$ & $0.415(3)$ & $0.040^{*}$ & \\
\hline N3 & $0.8590(2)$ & $0.44846(19)$ & $0.10435(15)$ & $0.0207(4)$ & \\
\hline $\mathrm{H} 3 \mathrm{~N}$ & $0.837(3)$ & $0.5114(16)$ & $0.0599(16)$ & $0.025^{*}$ & \\
\hline N4 & $0.9200(2)$ & 0.45225 (19) & $0.17342(14)$ & $0.0204(4)$ & \\
\hline $\mathrm{C} 16$ & $0.8112(3)$ & $0.3530(2)$ & $0.11379(17)$ & $0.0196(5)$ & \\
\hline $\mathrm{C} 17$ & $0.9657(3)$ & $0.5459(2)$ & $0.16018(17)$ & $0.0194(5)$ & \\
\hline H17 & 0.957185 & 0.607260 & 0.104159 & $0.023^{*}$ & \\
\hline $\mathrm{C} 18$ & $1.0297(3)$ & $0.5591(2)$ & $0.22915(17)$ & $0.0190(5)$ & \\
\hline C19 & $1.0386(3)$ & $0.4737(2)$ & $0.31632(18)$ & $0.0194(5)$ & \\
\hline $\mathrm{C} 20$ & $1.0996(3)$ & $0.4913(2)$ & $0.38046(17)$ & $0.0209(5)$ & \\
\hline $\mathrm{H} 20$ & 1.105178 & 0.433873 & 0.438900 & $0.025^{*}$ & \\
\hline $\mathrm{C} 21$ & $1.1521(3)$ & $0.5920(2)$ & $0.35942(18)$ & $0.0203(5)$ & \\
\hline $\mathrm{C} 22$ & $1.1458(3)$ & $0.6781(2)$ & $0.27344(18)$ & $0.0215(5)$ & \\
\hline $\mathrm{H} 22$ & 1.182843 & 0.747006 & 0.259188 & $0.026^{*}$ & \\
\hline $\mathrm{C} 23$ & $1.0847(3)$ & $0.6603(2)$ & $0.21012(18)$ & $0.0216(5)$ & \\
\hline $\mathrm{H} 23$ & 1.079627 & 0.718240 & 0.151889 & $0.026^{*}$ & \\
\hline $\mathrm{C} 24$ & $0.7519(3)$ & $0.1325(2)$ & $0.20774(19)$ & $0.0251(6)$ & \\
\hline $\mathrm{H} 24 \mathrm{~A}$ & 0.646424 & 0.163586 & 0.200085 & $0.030^{*}$ & \\
\hline $\mathrm{H} 24 \mathrm{~B}$ & 0.808039 & 0.107821 & 0.153245 & $0.030^{*}$ & \\
\hline $\mathrm{C} 25$ & $0.7547(3)$ & $0.0327(2)$ & 0.29619 (19) & $0.0226(5)$ & \\
\hline $\mathrm{C} 26$ & $0.8227(3)$ & $-0.0766(2)$ & $0.2930(2)$ & $0.0265(6)$ & \\
\hline $\mathrm{H} 26$ & 0.871663 & -0.087477 & 0.234705 & $0.032^{*}$ & \\
\hline $\mathrm{C} 27$ & $0.8194(3)$ & $-0.1692(2)$ & $0.3740(2)$ & $0.0283(6)$ & \\
\hline $\mathrm{H} 27$ & 0.863323 & -0.243353 & 0.370793 & $0.034^{*}$ & \\
\hline $\mathrm{C} 28$ & $0.7522(3)$ & $-0.1537(2)$ & $0.4595(2)$ & $0.0284(6)$ & \\
\hline $\mathrm{H} 28$ & 0.750406 & -0.217124 & 0.515075 & $0.034^{*}$ & \\
\hline $\mathrm{C} 29$ & $0.6876(3)$ & $-0.0454(2)$ & $0.4638(2)$ & $0.0265(6)$ & \\
\hline $\mathrm{H} 29$ & 0.643968 & -0.034434 & 0.522644 & $0.032 *$ & \\
\hline $\mathrm{C} 30$ & $0.6862(3)$ & $0.0475(2)$ & $0.38258(19)$ & $0.0234(5)$ & \\
\hline $\mathrm{H} 30$ & 0.638612 & 0.121017 & 0.385989 & $0.028^{*}$ & \\
\hline $\mathrm{C} 31$ & $0.7275(4)$ & $0.9684(3)$ & $-0.0089(2)$ & $0.0405(8)$ & 0.5 \\
\hline $\mathrm{H} 31$ & 0.665510 & 0.932384 & -0.030137 & $0.049^{*}$ & 0.5 \\
\hline $\mathrm{C} 11$ & $0.8790(2)$ & $1.01634(17)$ & $-0.10182(14)$ & $0.0566(5)$ & 0.5 \\
\hline $\mathrm{Cl} 2$ & $0.6144(2)$ & $1.09856(18)$ & $0.01277(17)$ & $0.0613(5)$ & 0.5 \\
\hline $\mathrm{Cl} 3$ & $0.7817(3)$ & $0.87623(19)$ & $0.08710(13)$ & $0.0687(7)$ & 0.5 \\
\hline $\mathrm{C} 31^{\prime}$ & $0.7275(4)$ & $0.9684(3)$ & $-0.0089(2)$ & $0.0405(8)$ & 0.5 \\
\hline
\end{tabular}




\begin{tabular}{llllll}
$\mathrm{H} 31^{\prime}$ & 0.685078 & 0.921358 & -0.032073 & $0.049^{*}$ & 0.5 \\
$\mathrm{Cl1}^{\prime}$ & $0.6989(5)$ & $1.0987(2)$ & $-0.07821(16)$ & $0.1146(14)$ & 0.5 \\
$\mathrm{Cl}^{\prime}$ & $0.6300(2)$ & $0.94980(17)$ & $0.10809(11)$ & $0.0516(4)$ & 0.5 \\
$\mathrm{Cl}^{\prime}$ & $0.9202(3)$ & $0.8995(4)$ & $-0.0011(3)$ & $0.1114(13)$ & 0.5 \\
\hline
\end{tabular}

Atomic displacement parameters $\left(\AA^{2}\right)$

\begin{tabular}{|c|c|c|c|c|c|c|}
\hline & $U^{11}$ & $U^{22}$ & $U^{33}$ & $U^{12}$ & $U^{13}$ & $U^{23}$ \\
\hline $\mathrm{S} 1$ & $0.0359(4)$ & 0.0259 & 0.0215 & $-0.0055(3)$ & -0.0130 & -0.0088 \\
\hline $\mathrm{S} 2$ & $0.0322(3)$ & 0.0233 & 0.0203 & -0.0048 & -0.0109 & -0.0055 \\
\hline $\mathrm{O} 1$ & $0.0327(10)$ & $0.0213(9)$ & $0.0208(9)$ & $-0.0084(8)$ & $-0.0120(8)$ & $-0.0040(7)$ \\
\hline $\mathrm{O} 2$ & $0.0322(10)$ & $0.0238(10)$ & $0.0229(10)$ & $-0.0075(8)$ & $-0.0121(8)$ & $-0.0060(8)$ \\
\hline N1 & $0.0257(11)$ & $0.0233(11)$ & $0.0181(10)$ & $-0.0035(9)$ & $-0.0090(9)$ & $-0.0061(9)$ \\
\hline N2 & $0.0212(10)$ & $0.0236(11)$ & $0.0193(10)$ & $-0.0020(9)$ & $-0.0079(8)$ & $-0.0086(9)$ \\
\hline $\mathrm{C} 1$ & $0.0213(12)$ & $0.0233(13)$ & $0.0188(12)$ & $-0.0019(10)$ & $-0.0056(10)$ & $-0.0071(10)$ \\
\hline $\mathrm{C} 2$ & $0.0221(12)$ & $0.0226(13)$ & $0.0163(12)$ & $-0.0017(10)$ & $-0.0050(10)$ & $-0.0049(10)$ \\
\hline $\mathrm{C} 3$ & $0.0190(11)$ & $0.0214(13)$ & $0.0180(12)$ & $-0.0023(10)$ & $-0.0044(9)$ & $-0.0076(10)$ \\
\hline $\mathrm{C} 4$ & $0.0177(11)$ & $0.0173(12)$ & $0.0199(12)$ & $-0.0010(9)$ & $-0.0043(9)$ & $-0.0061(10)$ \\
\hline $\mathrm{C} 5$ & $0.0231(12)$ & $0.0181(12)$ & $0.0170(12)$ & $-0.0007(10)$ & $-0.0072(10)$ & $-0.0042(10)$ \\
\hline C6 & $0.0182(11)$ & $0.0226(13)$ & $0.0209(12)$ & $-0.0017(10)$ & $-0.0044(10)$ & $-0.0095(10)$ \\
\hline $\mathrm{C} 7$ & $0.0262(13)$ & $0.0181(12)$ & $0.0225(13)$ & $-0.0062(10)$ & $-0.0053(10)$ & $-0.0059(10)$ \\
\hline $\mathrm{C} 8$ & $0.0252(13)$ & $0.0206(13)$ & $0.0170(12)$ & $-0.0047(10)$ & $-0.0043(10)$ & $-0.0028(10)$ \\
\hline $\mathrm{C} 9$ & $0.0379(15)$ & $0.0237(14)$ & $0.0288(14)$ & $-0.0070(12)$ & $-0.0150(12)$ & $-0.0067(12)$ \\
\hline $\mathrm{C} 10$ & $0.0300(14)$ & $0.0203(13)$ & $0.0274(14)$ & $-0.0056(11)$ & $-0.0114(11)$ & $-0.0087(11)$ \\
\hline C11 & $0.0241(13)$ & $0.0304(15)$ & $0.0345(15)$ & $-0.0015(11)$ & $-0.0126(12)$ & $-0.0133(12)$ \\
\hline $\mathrm{C} 12$ & $0.0242(13)$ & $0.0322(15)$ & $0.0335(15)$ & $-0.0089(11)$ & $-0.0043(11)$ & $-0.0144(13)$ \\
\hline $\mathrm{C} 13$ & $0.0304(14)$ & $0.0193(13)$ & $0.0272(14)$ & $-0.0072(11)$ & $-0.0073(11)$ & $-0.0071(11)$ \\
\hline $\mathrm{C} 14$ & $0.0241(13)$ & $0.0208(13)$ & $0.0321(14)$ & $-0.0013(10)$ & $-0.0097(11)$ & $-0.0090(11)$ \\
\hline $\mathrm{C} 15$ & 0.0235 & 0.0249 (14) & $0.0280(14)$ & $-0.0068(11)$ & $-0.0047(11)$ & $-0.0087(11)$ \\
\hline S3 & $0.0301(3)$ & 0.0270 & $0.0196(3)$ & $-0.0083(3)$ & $-0.0105(3)$ & $-0.0077(3)$ \\
\hline $\mathrm{S} 4$ & 0.0284 & 0.0239 & 0.0211 & -0.0101 & $-0.0106(2)$ & -0.0043 \\
\hline $\mathrm{O} 3$ & $0.0343(10)$ & $0.0253(10)$ & $0.0215(9)$ & $-0.0117(8)$ & $-0.0102(8)$ & $-0.0046(8)$ \\
\hline $\mathrm{O} 4$ & $0.0341(10)$ & $0.0253(10)$ & $0.0279(10)$ & $-0.0056(8)$ & $-0.0158(8)$ & $-0.0097(9)$ \\
\hline N3 & $0.0259(11)$ & $0.0222(11)$ & $0.0173(10)$ & $-0.0073(9)$ & $-0.0079(9)$ & $-0.0051(9)$ \\
\hline N4 & $0.0213(10)$ & $0.0250(11)$ & $0.0184(10)$ & -0.0049 (9) & $-0.0066(8)$ & $-0.0082(9)$ \\
\hline $\mathrm{C} 16$ & $0.0195(11)$ & $0.0216(13)$ & $0.0181(12)$ & $-0.0032(10)$ & $-0.0046(9)$ & $-0.0062(10)$ \\
\hline $\mathrm{C} 17$ & $0.0196(11)$ & $0.0209(13)$ & $0.0178(12)$ & $-0.0032(10)$ & $-0.0046(9)$ & $-0.0056(10)$ \\
\hline C18 & $0.0169(11)$ & $0.0221(13)$ & $0.0187(12)$ & $-0.0025(9)$ & $-0.0035(9)$ & $-0.0077(10)$ \\
\hline C19 & $0.0180(11)$ & $0.0216(13)$ & $0.0208(12)$ & $-0.0030(10)$ & $-0.0042(9)$ & $-0.0091(10)$ \\
\hline $\mathrm{C} 20$ & $0.0224(12)$ & $0.0228(13)$ & $0.0173(12)$ & $-0.0020(10)$ & $-0.0057(10)$ & $-0.0059(10)$ \\
\hline $\mathrm{C} 21$ & 0.0181 & $0.0251(13)$ & $0.0221(12)$ & $-0.0002(10)$ & $-0.0076(10)$ & $-0.0120(11)$ \\
\hline $\mathrm{C} 22$ & $0.0218(12)$ & $0.0209(13)$ & $0.0249(13)$ & $-0.0047(10)$ & $-0.0060(10)$ & $-0.0091(11)$ \\
\hline $\mathrm{C} 23$ & $0.0229(12)$ & $0.0228(13)$ & $0.0199(12)$ & $-0.0034(10)$ & $-0.0066(10)$ & $-0.0063(10)$ \\
\hline $\mathrm{C} 24$ & $0.0301(14)$ & $0.0246(14)$ & $0.0269(14)$ & $-0.0097(11)$ & $-0.0096(11)$ & $-0.0092(11)$ \\
\hline $\mathrm{C} 25$ & $0.0205(12)$ & $0.0241(13)$ & $0.0269(13)$ & $-0.0082(10)$ & $-0.0077(10)$ & $-0.0074(11)$ \\
\hline $\mathrm{C} 26$ & $0.0235(13)$ & $0.0296(15)$ & $0.0322(15)$ & $-0.0084(11)$ & $-0.0043(11)$ & $-0.0150(12)$ \\
\hline $\mathrm{C} 27$ & $0.0221(13)$ & $0.0208(14)$ & $0.0428(17)$ & $-0.0037(10)$ & $-0.0053(12)$ & $-0.0116(12)$ \\
\hline $\mathrm{C} 28$ & $0.0239(13)$ & $0.0233(14)$ & $0.0329(15)$ & $-0.0068(11)$ & $-0.0060(11)$ & $-0.0009(12)$ \\
\hline
\end{tabular}




\begin{tabular}{lllllll} 
C29 & $0.0240(13)$ & $0.0296(15)$ & $0.0265(14)$ & $-0.0068(11)$ & $-0.0038(11)$ & $-0.0088(12)$ \\
C30 & $0.0217(12)$ & $0.0218(13)$ & $0.0301(14)$ & $-0.0048(10)$ & $-0.0074(11)$ & $-0.0099(11)$ \\
C31 & $0.0448(19)$ & $0.051(2)$ & $0.0349(17)$ & $-0.0165(16)$ & $-0.0082(14)$ & $-0.0181(15)$ \\
C11 & $0.0650(12)$ & $0.0526(11)$ & $0.0532(11)$ & $-0.0339(9)$ & $0.0188(9)$ & $-0.0247(9)$ \\
C12 & $0.0574(11)$ & $0.0547(11)$ & $0.0867(15)$ & $-0.0157(9)$ & $0.0009(10)$ & $-0.0467(11)$ \\
C13 & $0.1172(19)$ & $0.0625(12)$ & $0.0413(10)$ & $-0.0488(13)$ & $-0.0460(11)$ & $0.0100(9)$ \\
C31' & $0.0448(19)$ & $0.051(2)$ & $0.0349(17)$ & $-0.0165(16)$ & $-0.0082(14)$ & $-0.0181(15)$ \\
C11 $^{\prime}$ & $0.262(5)$ & $0.0535(14)$ & $0.0460(12)$ & $-0.084(2)$ & $-0.0433(19)$ & $0.0102(10)$ \\
C12 $^{\prime}$ & $0.0670(11)$ & $0.0606(11)$ & $0.0290(8)$ & $-0.0103(9)$ & $-0.0098(8)$ & $-0.0161(8)$ \\
C13 $^{\prime}$ & $0.0426(12)$ & $0.209(4)$ & $0.132(3)$ & $-0.0222(17)$ & $-0.0122(14)$ & $-0.115(3)$ \\
\hline
\end{tabular}

Geometric parameters $\left(\AA,{ }^{\circ}\right)$

\begin{tabular}{|c|c|c|c|}
\hline $\mathrm{S} 1-\mathrm{C} 1$ & $1.680(3)$ & $\mathrm{O} 3-\mathrm{H} 3 \mathrm{O}$ & $0.78(4)$ \\
\hline $\mathrm{S} 2-\mathrm{C} 1$ & $1.755(3)$ & $\mathrm{O} 4-\mathrm{C} 21$ & $1.369(3)$ \\
\hline S2-C9 & $1.816(3)$ & $\mathrm{O} 4-\mathrm{H} 4 \mathrm{O}$ & $0.75(4)$ \\
\hline $\mathrm{O} 1-\mathrm{C} 4$ & $1.352(3)$ & $\mathrm{N} 3-\mathrm{C} 16$ & $1.340(3)$ \\
\hline $\mathrm{O} 1-\mathrm{H} 1 \mathrm{O}$ & $0.835(10)$ & $\mathrm{N} 3-\mathrm{N} 4$ & $1.376(3)$ \\
\hline $\mathrm{O} 2-\mathrm{C} 6$ & $1.352(3)$ & $\mathrm{N} 3-\mathrm{H} 3 \mathrm{~N}$ & $0.875(10)$ \\
\hline $\mathrm{O} 2-\mathrm{H} 2 \mathrm{O}$ & $0.77(4)$ & $\mathrm{N} 4-\mathrm{C} 17$ & $1.291(3)$ \\
\hline $\mathrm{N} 1-\mathrm{C} 1$ & $1.327(3)$ & $\mathrm{C} 17-\mathrm{C} 18$ & $1.446(3)$ \\
\hline $\mathrm{N} 1-\mathrm{N} 2$ & 1.377 (3) & $\mathrm{C} 17-\mathrm{H} 17$ & 0.9500 \\
\hline $\mathrm{N} 1-\mathrm{H} 1 \mathrm{~N}$ & $0.881(10)$ & $\mathrm{C} 18-\mathrm{C} 23$ & $1.405(4)$ \\
\hline $\mathrm{N} 2-\mathrm{C} 2$ & $1.289(3)$ & $\mathrm{C} 18-\mathrm{C} 19$ & $1.417(4)$ \\
\hline $\mathrm{C} 2-\mathrm{C} 3$ & $1.441(3)$ & $\mathrm{C} 19-\mathrm{C} 20$ & $1.389(3)$ \\
\hline $\mathrm{C} 2-\mathrm{H} 2$ & 0.9500 & $\mathrm{C} 20-\mathrm{C} 21$ & $1.380(4)$ \\
\hline $\mathrm{C} 3-\mathrm{C} 8$ & $1.406(4)$ & $\mathrm{C} 20-\mathrm{H} 20$ & 0.9500 \\
\hline $\mathrm{C} 3-\mathrm{C} 4$ & $1.419(3)$ & $\mathrm{C} 21-\mathrm{C} 22$ & $1.404(4)$ \\
\hline $\mathrm{C} 4-\mathrm{C} 5$ & $1.388(3)$ & $\mathrm{C} 22-\mathrm{C} 23$ & $1.380(3)$ \\
\hline $\mathrm{C} 5-\mathrm{C} 6$ & $1.385(4)$ & $\mathrm{C} 22-\mathrm{H} 22$ & 0.9500 \\
\hline $\mathrm{C} 5-\mathrm{H} 5$ & 0.9500 & $\mathrm{C} 23-\mathrm{H} 23$ & 0.9500 \\
\hline $\mathrm{C} 6-\mathrm{C} 7$ & $1.410(4)$ & $\mathrm{C} 24-\mathrm{C} 25$ & $1.508(4)$ \\
\hline $\mathrm{C} 7-\mathrm{C} 8$ & $1.379(4)$ & $\mathrm{C} 24-\mathrm{H} 24 \mathrm{~A}$ & 0.9900 \\
\hline $\mathrm{C} 7-\mathrm{H} 7$ & 0.9500 & $\mathrm{C} 24-\mathrm{H} 24 \mathrm{~B}$ & 0.9900 \\
\hline $\mathrm{C} 8-\mathrm{H} 8$ & 0.9500 & $\mathrm{C} 25-\mathrm{C} 30$ & $1.395(4)$ \\
\hline $\mathrm{C} 9-\mathrm{C} 10$ & $1.512(4)$ & $\mathrm{C} 25-\mathrm{C} 26$ & $1.399(4)$ \\
\hline C9-H9A & 0.9900 & $\mathrm{C} 26-\mathrm{C} 27$ & $1.387(4)$ \\
\hline C9-H9B & 0.9900 & $\mathrm{C} 26-\mathrm{H} 26$ & 0.9500 \\
\hline $\mathrm{C} 10-\mathrm{C} 11$ & $1.394(4)$ & $\mathrm{C} 27-\mathrm{C} 28$ & $1.384(4)$ \\
\hline $\mathrm{C} 10-\mathrm{C} 15$ & $1.403(4)$ & $\mathrm{C} 27-\mathrm{H} 27$ & 0.9500 \\
\hline $\mathrm{C} 11-\mathrm{C} 12$ & $1.385(4)$ & $\mathrm{C} 28-\mathrm{C} 29$ & $1.386(4)$ \\
\hline C11-H11 & 0.9500 & $\mathrm{C} 28-\mathrm{H} 28$ & 0.9500 \\
\hline $\mathrm{C} 12-\mathrm{C} 13$ & $1.388(4)$ & $\mathrm{C} 29-\mathrm{C} 30$ & $1.393(4)$ \\
\hline C12-H12 & 0.9500 & $\mathrm{C} 29-\mathrm{H} 29$ & 0.9500 \\
\hline $\mathrm{C} 13-\mathrm{C} 14$ & $1.392(4)$ & $\mathrm{C} 30-\mathrm{H} 30$ & 0.9500 \\
\hline C13-H13 & 0.9500 & $\mathrm{C} 31-\mathrm{Cl} 3$ & $1.660(4)$ \\
\hline $\mathrm{C} 14-\mathrm{C} 15$ & $1.386(4)$ & C31-Cl1 & $1.774(4)$ \\
\hline $\mathrm{C} 14-\mathrm{H} 14$ & 0.9500 & $\mathrm{C} 31-\mathrm{C} 22$ & $1.832(4)$ \\
\hline
\end{tabular}




\begin{tabular}{|c|c|c|c|}
\hline $\mathrm{C} 15-\mathrm{H} 15$ & 0.9500 & $\mathrm{C} 31-\mathrm{H} 31$ & 1.0000 \\
\hline $\mathrm{S} 3-\mathrm{C} 16$ & $1.675(2)$ & $\mathrm{C} 31^{\prime}-\mathrm{C} 11^{\prime}$ & $1.628(4)$ \\
\hline $\mathrm{S} 4-\mathrm{C} 16$ & $1.749(3)$ & $\mathrm{C} 31^{\prime}-\mathrm{Cl} 2^{\prime}$ & $1.773(4)$ \\
\hline $\mathrm{S} 4-\mathrm{C} 24$ & $1.823(3)$ & $\mathrm{C} 31^{\prime}-\mathrm{Cl}^{\prime}$ & $1.815(4)$ \\
\hline $\mathrm{O} 3-\mathrm{C} 19$ & $1.351(3)$ & $\mathrm{C} 31^{\prime}-\mathrm{H} 31^{\prime}$ & 1.0000 \\
\hline $\mathrm{C} 1-\mathrm{S} 2-\mathrm{C} 9$ & $102.06(13)$ & $\mathrm{C} 17-\mathrm{N} 4-\mathrm{N} 3$ & $116.9(2)$ \\
\hline $\mathrm{C} 4-\mathrm{O} 1-\mathrm{H} 1 \mathrm{O}$ & $108(2)$ & $\mathrm{N} 3-\mathrm{C} 16-\mathrm{S} 3$ & $121.44(19)$ \\
\hline $\mathrm{C} 6-\mathrm{O} 2-\mathrm{H} 2 \mathrm{O}$ & $108(3)$ & $\mathrm{N} 3-\mathrm{C} 16-\mathrm{S} 4$ & 114.31 \\
\hline $\mathrm{C} 1-\mathrm{N} 1-\mathrm{N} 2$ & $120.7(2)$ & $\mathrm{S} 3-\mathrm{C} 16-\mathrm{S} 4$ & $124.25(16)$ \\
\hline $\mathrm{C} 1-\mathrm{N} 1-\mathrm{H} 1 \mathrm{~N}$ & $121(2)$ & $\mathrm{N} 4-\mathrm{C} 17-\mathrm{C} 18$ & $121.1(2)$ \\
\hline $\mathrm{N} 2-\mathrm{N} 1-\mathrm{H} 1 \mathrm{~N}$ & $118(2)$ & $\mathrm{N} 4-\mathrm{C} 17-\mathrm{H} 17$ & 119.4 \\
\hline $\mathrm{C} 2-\mathrm{N} 2-\mathrm{N} 1$ & $116.2(2)$ & $\mathrm{C} 18-\mathrm{C} 17-\mathrm{H} 17$ & 119.4 \\
\hline $\mathrm{N} 1-\mathrm{C} 1-\mathrm{S} 1$ & $120.7(2)$ & $\mathrm{C} 23-\mathrm{C} 18-\mathrm{C} 19$ & $118.1(2)$ \\
\hline $\mathrm{N} 1-\mathrm{C} 1-\mathrm{S} 2$ & $114.43(19)$ & $\mathrm{C} 23-\mathrm{C} 18-\mathrm{C} 17$ & $119.3(2)$ \\
\hline $\mathrm{S} 1-\mathrm{C} 1-\mathrm{S} 2$ & $124.88(16)$ & $\mathrm{C} 19-\mathrm{C} 18-\mathrm{C} 17$ & $122.6(2)$ \\
\hline $\mathrm{N} 2-\mathrm{C} 2-\mathrm{C} 3$ & $121.5(2)$ & $\mathrm{O} 3-\mathrm{C} 19-\mathrm{C} 20$ & $117.1(2)$ \\
\hline $\mathrm{N} 2-\mathrm{C} 2-\mathrm{H} 2$ & 119.3 & $\mathrm{O} 3-\mathrm{C} 19-\mathrm{C} 18$ & $122.7(2)$ \\
\hline $\mathrm{C} 3-\mathrm{C} 2-\mathrm{H} 2$ & 119.3 & $\mathrm{C} 20-\mathrm{C} 19-\mathrm{C} 18$ & $120.2(2)$ \\
\hline $\mathrm{C} 8-\mathrm{C} 3-\mathrm{C} 4$ & $117.9(2)$ & $\mathrm{C} 21-\mathrm{C} 20-\mathrm{C} 19$ & $120.1(2)$ \\
\hline $\mathrm{C} 8-\mathrm{C} 3-\mathrm{C} 2$ & $119.8(2)$ & $\mathrm{C} 21-\mathrm{C} 20-\mathrm{H} 20$ & 120.0 \\
\hline $\mathrm{C} 4-\mathrm{C} 3-\mathrm{C} 2$ & $122.3(2)$ & $\mathrm{C} 19-\mathrm{C} 20-\mathrm{H} 20$ & 120.0 \\
\hline $\mathrm{O} 1-\mathrm{C} 4-\mathrm{C} 5$ & $117.3(2)$ & $\mathrm{O} 4-\mathrm{C} 21-\mathrm{C} 20$ & $117.0(2)$ \\
\hline $\mathrm{O} 1-\mathrm{C} 4-\mathrm{C} 3$ & $122.6(2)$ & $\mathrm{O} 4-\mathrm{C} 21-\mathrm{C} 22$ & $121.8(2)$ \\
\hline $\mathrm{C} 5-\mathrm{C} 4-\mathrm{C} 3$ & $120.1(2)$ & $\mathrm{C} 20-\mathrm{C} 21-\mathrm{C} 22$ & $121.2(2)$ \\
\hline $\mathrm{C} 6-\mathrm{C} 5-\mathrm{C} 4$ & $120.6(2)$ & $\mathrm{C} 23-\mathrm{C} 22-\mathrm{C} 21$ & $118.5(2)$ \\
\hline $\mathrm{C} 6-\mathrm{C} 5-\mathrm{H} 5$ & 119.7 & $\mathrm{C} 23-\mathrm{C} 22-\mathrm{H} 22$ & 120.8 \\
\hline $\mathrm{C} 4-\mathrm{C} 5-\mathrm{H} 5$ & 119.7 & $\mathrm{C} 21-\mathrm{C} 22-\mathrm{H} 22$ & 120.8 \\
\hline $\mathrm{O} 2-\mathrm{C} 6-\mathrm{C} 5$ & $122.1(2)$ & $\mathrm{C} 22-\mathrm{C} 23-\mathrm{C} 18$ & $122.0(2)$ \\
\hline $\mathrm{O} 2-\mathrm{C} 6-\mathrm{C} 7$ & $117.3(2)$ & $\mathrm{C} 22-\mathrm{C} 23-\mathrm{H} 23$ & 119.0 \\
\hline $\mathrm{C} 5-\mathrm{C} 6-\mathrm{C} 7$ & $120.6(2)$ & $\mathrm{C} 18-\mathrm{C} 23-\mathrm{H} 23$ & 119.0 \\
\hline $\mathrm{C} 8-\mathrm{C} 7-\mathrm{C} 6$ & $118.5(2)$ & $\mathrm{C} 25-\mathrm{C} 24-\mathrm{S} 4$ & 108.18 \\
\hline $\mathrm{C} 8-\mathrm{C} 7-\mathrm{H} 7$ & 120.8 & $\mathrm{C} 25-\mathrm{C} 24-\mathrm{H} 24 \mathrm{~A}$ & 110.1 \\
\hline $\mathrm{C} 6-\mathrm{C} 7-\mathrm{H} 7$ & 120.8 & $\mathrm{~S} 4-\mathrm{C} 24-\mathrm{H} 24 \mathrm{~A}$ & 110.1 \\
\hline $\mathrm{C} 7-\mathrm{C} 8-\mathrm{C} 3$ & $122.4(2)$ & $\mathrm{C} 25-\mathrm{C} 24-\mathrm{H} 24 \mathrm{~B}$ & 110.1 \\
\hline $\mathrm{C} 7-\mathrm{C} 8-\mathrm{H} 8$ & 118.8 & $\mathrm{~S} 4-\mathrm{C} 24-\mathrm{H} 24 \mathrm{~B}$ & 110.1 \\
\hline $\mathrm{C} 3-\mathrm{C} 8-\mathrm{H} 8$ & 118.8 & $\mathrm{H} 24 \mathrm{~A}-\mathrm{C} 24-\mathrm{H} 24 \mathrm{~B}$ & 108.4 \\
\hline $\mathrm{C} 10-\mathrm{C} 9-\mathrm{S} 2$ & $108.38(18)$ & $\mathrm{C} 30-\mathrm{C} 25-\mathrm{C} 26$ & $118.8(3)$ \\
\hline $\mathrm{C} 10-\mathrm{C} 9-\mathrm{H} 9 \mathrm{~A}$ & 110.0 & $\mathrm{C} 30-\mathrm{C} 25-\mathrm{C} 24$ & $120.5(2)$ \\
\hline $\mathrm{S} 2-\mathrm{C} 9-\mathrm{H} 9 \mathrm{~A}$ & 110.0 & $\mathrm{C} 26-\mathrm{C} 25-\mathrm{C} 24$ & $120.7(2)$ \\
\hline $\mathrm{C} 10-\mathrm{C} 9-\mathrm{H} 9 \mathrm{~B}$ & 110.0 & $\mathrm{C} 27-\mathrm{C} 26-\mathrm{C} 25$ & $120.7(3)$ \\
\hline $\mathrm{S} 2-\mathrm{C} 9-\mathrm{H} 9 \mathrm{~B}$ & 110.0 & $\mathrm{C} 27-\mathrm{C} 26-\mathrm{H} 26$ & 119.7 \\
\hline $\mathrm{H} 9 \mathrm{~A}-\mathrm{C} 9-\mathrm{H} 9 \mathrm{~B}$ & 108.4 & $\mathrm{C} 25-\mathrm{C} 26-\mathrm{H} 26$ & 119.7 \\
\hline $\mathrm{C} 11-\mathrm{C} 10-\mathrm{C} 15$ & $119.0(3)$ & $\mathrm{C} 28-\mathrm{C} 27-\mathrm{C} 26$ & $120.1(3)$ \\
\hline $\mathrm{C} 11-\mathrm{C} 10-\mathrm{C} 9$ & $120.3(2)$ & $\mathrm{C} 28-\mathrm{C} 27-\mathrm{H} 27$ & 119.9 \\
\hline $\mathrm{C} 15-\mathrm{C} 10-\mathrm{C} 9$ & $120.7(3)$ & $\mathrm{C} 26-\mathrm{C} 27-\mathrm{H} 27$ & 119.9 \\
\hline $\mathrm{C} 12-\mathrm{C} 11-\mathrm{C} 10$ & $120.4(3)$ & $\mathrm{C} 27-\mathrm{C} 28-\mathrm{C} 29$ & $119.7(3)$ \\
\hline $\mathrm{C} 12-\mathrm{C} 11-\mathrm{H} 11$ & 119.8 & $\mathrm{C} 27-\mathrm{C} 28-\mathrm{H} 28$ & 120.1 \\
\hline
\end{tabular}




\begin{tabular}{|c|c|c|c|}
\hline $\mathrm{C} 10-\mathrm{C} 11-\mathrm{H} 11$ & 119.8 & $\mathrm{C} 29-\mathrm{C} 28-\mathrm{H} 28$ & 120.1 \\
\hline $\mathrm{C} 11-\mathrm{C} 12-\mathrm{C} 13$ & $120.3(3)$ & $\mathrm{C} 28-\mathrm{C} 29-\mathrm{C} 30$ & $120.5(3)$ \\
\hline $\mathrm{C} 11-\mathrm{C} 12-\mathrm{H} 12$ & 119.9 & $\mathrm{C} 28-\mathrm{C} 29-\mathrm{H} 29$ & 119.8 \\
\hline $\mathrm{C} 13-\mathrm{C} 12-\mathrm{H} 12$ & 119.9 & $\mathrm{C} 30-\mathrm{C} 29-\mathrm{H} 29$ & 119.8 \\
\hline $\mathrm{C} 12-\mathrm{C} 13-\mathrm{C} 14$ & $120.1(3)$ & $\mathrm{C} 29-\mathrm{C} 30-\mathrm{C} 25$ & $120.1(2)$ \\
\hline $\mathrm{C} 12-\mathrm{C} 13-\mathrm{H} 13$ & 120.0 & $\mathrm{C} 29-\mathrm{C} 30-\mathrm{H} 30$ & 120.0 \\
\hline $\mathrm{C} 14-\mathrm{C} 13-\mathrm{H} 13$ & 120.0 & $\mathrm{C} 25-\mathrm{C} 30-\mathrm{H} 30$ & 120.0 \\
\hline $\mathrm{C} 15-\mathrm{C} 14-\mathrm{C} 13$ & $119.7(2)$ & $\mathrm{Cl} 3-\mathrm{C} 31-\mathrm{Cl} 1$ & $114.0(2)$ \\
\hline $\mathrm{C} 15-\mathrm{C} 14-\mathrm{H} 14$ & 120.1 & $\mathrm{Cl} 3-\mathrm{C} 31-\mathrm{Cl} 2$ & $111.0(2)$ \\
\hline $\mathrm{C} 13-\mathrm{C} 14-\mathrm{H} 14$ & 120.1 & $\mathrm{C} 11-\mathrm{C} 31-\mathrm{Cl} 2$ & $104.6(2)$ \\
\hline $\mathrm{C} 14-\mathrm{C} 15-\mathrm{C} 10$ & $120.6(3)$ & $\mathrm{Cl} 3-\mathrm{C} 31-\mathrm{H} 31$ & 109.0 \\
\hline $\mathrm{C} 14-\mathrm{C} 15-\mathrm{H} 15$ & 119.7 & $\mathrm{Cl} 1-\mathrm{C} 31-\mathrm{H} 31$ & 109.0 \\
\hline $\mathrm{C} 10-\mathrm{C} 15-\mathrm{H} 15$ & 119.7 & $\mathrm{Cl} 2-\mathrm{C} 31-\mathrm{H} 31$ & 109.0 \\
\hline $\mathrm{C} 16-\mathrm{S} 4-\mathrm{C} 24$ & $101.78(12)$ & $\mathrm{C} 11^{\prime}-\mathrm{C} 31^{\prime}-\mathrm{Cl} 2^{\prime}$ & $113.8(2)$ \\
\hline $\mathrm{C} 19-\mathrm{O} 3-\mathrm{H} 3 \mathrm{O}$ & $108(3)$ & $\mathrm{C} 11^{\prime}-\mathrm{C} 31^{\prime}-\mathrm{Cl} 3^{\prime}$ & $118.7(3)$ \\
\hline $\mathrm{C} 21-\mathrm{O} 4-\mathrm{H} 4 \mathrm{O}$ & $113(3)$ & $\mathrm{Cl} 2^{\prime}-\mathrm{C} 31^{\prime}-\mathrm{Cl}^{\prime}$ & $105.1(2)$ \\
\hline $\mathrm{C} 16-\mathrm{N} 3-\mathrm{N} 4$ & $119.5(2)$ & $\mathrm{C} 11^{\prime}-\mathrm{C} 31^{\prime}-\mathrm{H} 31^{\prime}$ & 106.1 \\
\hline $\mathrm{C} 16-\mathrm{N} 3-\mathrm{H} 3 \mathrm{~N}$ & $120(2)$ & $\mathrm{Cl} 2^{\prime}-\mathrm{C} 31^{\prime}-\mathrm{H} 31^{\prime}$ & 106.1 \\
\hline $\mathrm{N} 4-\mathrm{N} 3-\mathrm{H} 3 \mathrm{~N}$ & $120(2)$ & $\mathrm{Cl} 3^{\prime}-\mathrm{C} 31^{\prime}-\mathrm{H} 31^{\prime}$ & 106.1 \\
\hline $\mathrm{C} 1-\mathrm{N} 1-\mathrm{N} 2-\mathrm{C} 2$ & $171.8(2)$ & $\mathrm{C} 16-\mathrm{N} 3-\mathrm{N} 4-\mathrm{C} 17$ & $179.3(2)$ \\
\hline $\mathrm{N} 2-\mathrm{N} 1-\mathrm{C} 1-\mathrm{S} 1$ & $-176.24(18)$ & $\mathrm{N} 4-\mathrm{N} 3-\mathrm{C} 16-\mathrm{S} 3$ & $178.63(18)$ \\
\hline $\mathrm{N} 2-\mathrm{N} 1-\mathrm{C} 1-\mathrm{S} 2$ & $3.8(3)$ & $\mathrm{N} 4-\mathrm{N} 3-\mathrm{C} 16-\mathrm{S} 4$ & $-1.7(3)$ \\
\hline $\mathrm{C} 9-\mathrm{S} 2-\mathrm{C} 1-\mathrm{N} 1$ & $-177.9(2)$ & $\mathrm{C} 24-\mathrm{S} 4-\mathrm{C} 16-\mathrm{N} 3$ & $176.56(19)$ \\
\hline $\mathrm{C} 9-\mathrm{S} 2-\mathrm{C} 1-\mathrm{S} 1$ & $2.2(2)$ & $\mathrm{C} 24-\mathrm{S} 4-\mathrm{C} 16-\mathrm{S} 3$ & $-3.8(2)$ \\
\hline $\mathrm{N} 1-\mathrm{N} 2-\mathrm{C} 2-\mathrm{C} 3$ & $-178.7(2)$ & $\mathrm{N} 3-\mathrm{N} 4-\mathrm{C} 17-\mathrm{C} 18$ & $179.1(2)$ \\
\hline $\mathrm{N} 2-\mathrm{C} 2-\mathrm{C} 3-\mathrm{C} 8$ & $-179.3(2)$ & $\mathrm{N} 4-\mathrm{C} 17-\mathrm{C} 18-\mathrm{C} 23$ & $177.0(2)$ \\
\hline $\mathrm{N} 2-\mathrm{C} 2-\mathrm{C} 3-\mathrm{C} 4$ & $0.9(4)$ & $\mathrm{N} 4-\mathrm{C} 17-\mathrm{C} 18-\mathrm{C} 19$ & $-3.4(4)$ \\
\hline $\mathrm{C} 8-\mathrm{C} 3-\mathrm{C} 4-\mathrm{O} 1$ & $179.0(2)$ & $\mathrm{C} 23-\mathrm{C} 18-\mathrm{C} 19-\mathrm{O} 3$ & $179.5(2)$ \\
\hline $\mathrm{C} 2-\mathrm{C} 3-\mathrm{C} 4-\mathrm{O} 1$ & $-1.3(4)$ & $\mathrm{C} 17-\mathrm{C} 18-\mathrm{C} 19-\mathrm{O} 3$ & $-0.1(4)$ \\
\hline $\mathrm{C} 8-\mathrm{C} 3-\mathrm{C} 4-\mathrm{C} 5$ & $-0.4(4)$ & $\mathrm{C} 23-\mathrm{C} 18-\mathrm{C} 19-\mathrm{C} 20$ & $0.3(4)$ \\
\hline $\mathrm{C} 2-\mathrm{C} 3-\mathrm{C} 4-\mathrm{C} 5$ & $179.4(2)$ & $\mathrm{C} 17-\mathrm{C} 18-\mathrm{C} 19-\mathrm{C} 20$ & $-179.3(2)$ \\
\hline $\mathrm{O} 1-\mathrm{C} 4-\mathrm{C} 5-\mathrm{C} 6$ & $179.7(2)$ & $\mathrm{O} 3-\mathrm{C} 19-\mathrm{C} 20-\mathrm{C} 21$ & $-179.4(2)$ \\
\hline $\mathrm{C} 3-\mathrm{C} 4-\mathrm{C} 5-\mathrm{C} 6$ & $-0.9(4)$ & $\mathrm{C} 18-\mathrm{C} 19-\mathrm{C} 20-\mathrm{C} 21$ & $-0.1(4)$ \\
\hline $\mathrm{C} 4-\mathrm{C} 5-\mathrm{C} 6-\mathrm{O} 2$ & $-178.9(2)$ & $\mathrm{C} 19-\mathrm{C} 20-\mathrm{C} 21-\mathrm{O} 4$ & $179.6(2)$ \\
\hline $\mathrm{C} 4-\mathrm{C} 5-\mathrm{C} 6-\mathrm{C} 7$ & $1.9(4)$ & $\mathrm{C} 19-\mathrm{C} 20-\mathrm{C} 21-\mathrm{C} 22$ & $-0.3(4)$ \\
\hline $\mathrm{O} 2-\mathrm{C} 6-\mathrm{C} 7-\mathrm{C} 8$ & $179.2(2)$ & $\mathrm{O} 4-\mathrm{C} 21-\mathrm{C} 22-\mathrm{C} 23$ & $-179.4(2)$ \\
\hline $\mathrm{C} 5-\mathrm{C} 6-\mathrm{C} 7-\mathrm{C} 8$ & $-1.5(4)$ & $\mathrm{C} 20-\mathrm{C} 21-\mathrm{C} 22-\mathrm{C} 23$ & $0.5(4)$ \\
\hline $\mathrm{C} 6-\mathrm{C} 7-\mathrm{C} 8-\mathrm{C} 3$ & $0.2(4)$ & $\mathrm{C} 21-\mathrm{C} 22-\mathrm{C} 23-\mathrm{C} 18$ & $-0.3(4)$ \\
\hline $\mathrm{C} 4-\mathrm{C} 3-\mathrm{C} 8-\mathrm{C} 7$ & $0.7(4)$ & $\mathrm{C} 19-\mathrm{C} 18-\mathrm{C} 23-\mathrm{C} 22$ & $-0.1(4)$ \\
\hline $\mathrm{C} 2-\mathrm{C} 3-\mathrm{C} 8-\mathrm{C} 7$ & $-179.1(2)$ & $\mathrm{C} 17-\mathrm{C} 18-\mathrm{C} 23-\mathrm{C} 22$ & $179.5(2)$ \\
\hline $\mathrm{C} 1-\mathrm{S} 2-\mathrm{C} 9-\mathrm{C} 10$ & $-175.43(19)$ & $\mathrm{C} 16-\mathrm{S} 4-\mathrm{C} 24-\mathrm{C} 25$ & $-174.94(18)$ \\
\hline $\mathrm{S} 2-\mathrm{C} 9-\mathrm{C} 10-\mathrm{C} 11$ & $97.7(3)$ & $\mathrm{S} 4-\mathrm{C} 24-\mathrm{C} 25-\mathrm{C} 30$ & $57.9(3)$ \\
\hline $\mathrm{S} 2-\mathrm{C} 9-\mathrm{C} 10-\mathrm{C} 15$ & $-81.2(3)$ & $\mathrm{S} 4-\mathrm{C} 24-\mathrm{C} 25-\mathrm{C} 26$ & $-123.6(2)$ \\
\hline $\mathrm{C} 15-\mathrm{C} 10-\mathrm{C} 11-\mathrm{C} 12$ & $0.0(4)$ & $\mathrm{C} 30-\mathrm{C} 25-\mathrm{C} 26-\mathrm{C} 27$ & $1.4(4)$ \\
\hline $\mathrm{C} 9-\mathrm{C} 10-\mathrm{C} 11-\mathrm{C} 12$ & $-178.9(2)$ & $\mathrm{C} 24-\mathrm{C} 25-\mathrm{C} 26-\mathrm{C} 27$ & $-177.1(2)$ \\
\hline $\mathrm{C} 10-\mathrm{C} 11-\mathrm{C} 12-\mathrm{C} 13$ & $0.6(4)$ & $\mathrm{C} 25-\mathrm{C} 26-\mathrm{C} 27-\mathrm{C} 28$ & $-1.9(4)$ \\
\hline $\mathrm{C} 11-\mathrm{C} 12-\mathrm{C} 13-\mathrm{C} 14$ & $-1.0(4)$ & $\mathrm{C} 26-\mathrm{C} 27-\mathrm{C} 28-\mathrm{C} 29$ & $0.3(4)$ \\
\hline
\end{tabular}




$\begin{array}{llll}\mathrm{C} 12-\mathrm{C} 13-\mathrm{C} 14-\mathrm{C} 15 & 0.8(4) & \mathrm{C} 27-\mathrm{C} 28-\mathrm{C} 29-\mathrm{C} 30 & 1.7(4) \\ \mathrm{C} 13-\mathrm{C} 14-\mathrm{C} 15-\mathrm{C} 10 & -0.2(4) & \mathrm{C} 28-\mathrm{C} 29-\mathrm{C} 30-\mathrm{C} 25 & -2.2(4) \\ \mathrm{C} 11-\mathrm{C} 10-\mathrm{C} 15-\mathrm{C} 14 & -0.2(4) & \mathrm{C} 26-\mathrm{C} 25-\mathrm{C} 30-\mathrm{C} 29 & 0.7(4) \\ \mathrm{C} 9-\mathrm{C} 10-\mathrm{C} 15-\mathrm{C} 14 & 178.7(2) & \mathrm{C} 24-\mathrm{C} 25-\mathrm{C} 30-\mathrm{C} 29 & 179.1(2)\end{array}$

Hydrogen-bond geometry $\left(\AA,{ }^{\circ}\right)$

$\mathrm{Cg} 1$ and $\mathrm{Cg} 2$ are the centroids of the (C10-C15) and (C25-C30) rings, respectively.

\begin{tabular}{|c|c|c|c|c|}
\hline$D-\mathrm{H} \cdots A$ & $D-\mathrm{H}$ & $\mathrm{H} \cdots A$ & $D \cdots A$ & $D-\mathrm{H} \cdots A$ \\
\hline $\mathrm{O} 1-\mathrm{H} 1 O \cdots \mathrm{N} 2$ & $0.83(3)$ & $1.91(3)$ & $2.653(3)$ & $148(3)$ \\
\hline $\mathrm{O} 3-\mathrm{H} 3 O \cdots \mathrm{N} 4$ & $0.78(4)$ & $1.97(4)$ & $2.663(3)$ & $148(4)$ \\
\hline $\mathrm{N} 1-\mathrm{H} 1 N \cdots \mathrm{S} 3^{\mathrm{i}}$ & $0.88(2)$ & $2.46(2)$ & $3.323(2)$ & $168(2)$ \\
\hline $\mathrm{N} 3-\mathrm{H} 3 N \cdots \mathrm{S} 1^{\mathrm{i}}$ & $0.88(2)$ & $2.53(2)$ & $3.394(2)$ & $171(2)$ \\
\hline $\mathrm{O} 2-\mathrm{H} 2 O \cdots \mathrm{O} 4^{\mathrm{ii}}$ & $0.76(4)$ & $2.09(4)$ & $2.841(3)$ & $170(4)$ \\
\hline $\mathrm{O} 4-\mathrm{H} 4 O O^{\cdots} \mathrm{Cg} 1^{\mathrm{iii}}$ & $0.75(4)$ & $3.00(4)$ & $3.735(3)$ & $170(4)$ \\
\hline $\mathrm{C} 27-\mathrm{H} 27 \cdots \mathrm{O} 2^{\mathrm{iv}}$ & 0.95 & 2.59 & $3.206(4)$ & 122 \\
\hline $\mathrm{C} 11-\mathrm{H} 11 \cdots C g 2^{\mathrm{v}}$ & 0.95 & 2.91 & $3.541(3)$ & 125 \\
\hline $\mathrm{C} 29-\mathrm{H} 29 \cdots C g 1^{\mathrm{vi}}$ & 0.95 & 2.87 & $3.506(3)$ & 125 \\
\hline $\mathrm{C} 26-\mathrm{H} 26 \cdots \mathrm{Cl} 1^{\mathrm{vii}}$ & 0.95 & 2.75 & $3.488(4)$ & 135 \\
\hline $\mathrm{C} 31-\mathrm{H} 31 \cdots \mathrm{Cl} 2^{\mathrm{viii}}$ & 1.00 & 2.66 & $3.512(4)$ & 143 \\
\hline $\mathrm{C} 31^{\prime}-\mathrm{H} 31^{\prime} \cdots \mathrm{S} 1^{\mathrm{i}}$ & 1.00 & 2.77 & $3.579(4)$ & 139 \\
\hline
\end{tabular}

Symmetry codes: (i) $-x+1,-y+1,-z$; (ii) $-x+2,-y+1,-z+1$; (iii) $x+1, y+1, z$; (iv) $x, y-1, z$; (v) $x-1, y, z$; (vi) $-x+1,-y,-z+1$; (vii) $-x+2,-y+1,-z$; (viii) $-x+1,-y+2,-z$. 